\title{
REVIEW
}

\section{Nature of relation between ventilation and oxygen consumption in filter feeders}

\author{
C. Barker Jørgensen ${ }^{1}$, Flemming Møhlenberg ${ }^{2}$ \& Ove Sten-Knudsen ${ }^{3}$ \\ ${ }^{1}$ Zoophysiological Laboratory A, August Krogh Institute, Universitetsparken 13, DK-2100 Copenhagen $\varnothing$, Denmark \\ ${ }^{2}$ Marine Pollution Laboratory, National Agency of Environmental Protection, Kavalergården 6, DK-2920 Charlottenlund, \\ Denmark \\ ${ }^{3}$ Institute of Biophysics, Panum Institute, Blegdamsvej 3C, DK-2200 Copenhagen N, Denmark
}

\begin{abstract}
Correlations between rates of ventilation and oxygen consumption in filter feeders are usually interpreted in terms of causal relations, but authors disagree on whether ventilation is regulated to meet respiratory needs or whether oxygen consumption reflects energetic costs of water transport. It seems, however, that neither causality applies, the correlations being determined by physical characteristics of the ventilatory systems. The ventilatory currents both in a tube dwelling worm, Urechis caupo, and in bivalves, such as Mytilus edulis, are laminar, and oxygen in the water is available to the animals solely by diffusion. Various estimates of the diffusive boundary layer $\delta$, developing at the interface between the ventilatory current and the body surface of $U$. caupo and mantle cavity in $M$. edulis, were in good agreement. The estimates of $\delta$ amounted to about $0.1 \mathrm{~mm}$, or a small fraction of the thickness of the ventilatory current, indicating that the larger part of the dissolved oxygen in the current is unavailable to the animals. At low rates of ventilation oxygen uptake is governed by the condition of diffusion in the ambient water. Oxygen consumption increases steeply with increasing ventilation until threshold levels are reached, and processes within the body become limiting for the rate of oxygen consumption. Oxygen consumption approaches independency of ventilation at ventilatory rates amounting to only one-fifth or less of the rates of the undisturbedly filtering animal. Regulation of respiration by means of ventilatory regulation thus seems incompatible with filter feeding in habitats that require high rates of water processing. The energetic costs of ventilation are insignificant. Presumably, in most habitats, water processing at low costs is a prerequisite for a life based on filter feeding
\end{abstract}

\section{INTRODUCTION}

Filter feeders are aquatic animals that obtain food by processing the ambient water in structures that retain food particles and other suspended particles. The material retained must yield more energy available to the organism than the energy needed to process the water. It is, therefore, of interest in studies of filter feeding to know the energetic costs of transporting water through the filters. Filter feeding has been adopted within most groups of aquatic animals, which utilize a variety of filtering structures, including setae, mucus nets, flagella, and cilia. Feeding currents often derive from respiratory currents, that is, the feeding structures have evolved from originally respiratory structures. This fact is reflected in the maintenance of the name gills for the feeding structures in filter feeding bivalves and other groups.

The basic requirement for turning gills into filter feeding structures is a many-fold increase in ventilation. This increase in capacity for water transport mostly results from the transformation of ancestral gill plates into filaments, thus greatly increasing the length of current-producing ciliary bands, e.g. in filter feeding bivalves and many gastropods. It was early recognized that water transport for filter feeding greatly exceeds the ventilation needed to cover the oxygen requirements of the organism, as indicated by the low extraction of oxygen from the ventilatory current. It was, however, assumed that the gills remained 
respiratory organs (White 1937, Krogh 1941, Ghiretti 1966).

Because of the over-dimensioning of the ventilation it could be expected that the rate of oxygen uptake would be rather insensitive to changes in ventilation rate. Measurements showed, however, that oxygen consumption varied with ventilation in filter feeders, such as Urechis caupo, bivalves, and others. These observations prompted interpretations in terms of causal relations between ventilation and oxygen consumption, which may not apply. It is the purpose of the present article to review such hypotheses and to present more coherent interpretations. These are supported by our own observations on the relation between ventilation and oxygen consumption in Mytilus edulis, in which ventilation was controlled by adjustment of the opening of the valves.

Symbols used. $\dot{\mathrm{V}}_{\mathrm{w}}$ is used to designate the volume of water processed per unit time, i.e. the ventilation; $\dot{\mathrm{M}}_{\mathrm{O}_{2}}$ the rate of oxygen consumption; $E_{w}$, the fraction of oxygen extracted from the water; $\mathrm{P}_{\mathrm{O}_{2}}$ oxygen tension; and $\dot{Q}$, the perfusion rate of the heart (Piiper et al. 1971, Dejours 1972).

\section{RELATIONS BETWEEN VENTILATION AND OXYGEN CONSUMPTION}

\section{Urechis caupo}

The echiuroid worm Urechis caupo lives in a $\mathrm{U}$ shaped burrow in the mud flats along the Californian coast. $U$. caupo ventilates the burrow by peristaltic contractions of the musculature of the body wall, originating at the anterior end and passing posteriorly. The peristaltic wave produces swelling of a body seg- ment that seals the tube and acts as a piston, forcing water backwards between the animal and the wall of the burrow. $U$, caupo feeds by filtering the current of water through a conical mucus net suspended between the anterior end of the body and the wall near the entrance to the burrow (Fisher \& MacGinitie 1928). It was early realized that $U$. caupo 'presents by virtue of its habits of life a unique opportunity for the quantitative study of the interrelations between muscular activity, rate of metabolism and the mechanism of exchange with the environment' (Hall 1931). U. caupo could be kept in the laboratory indefinitely if placed in glass tubes of dimensions similar to those of the burrow and given access to fresh sea water. Hall measured the volume of water pumped through the tube, as well as the drop in oxygen content between the water entering and leaving the tube, from which data the oxygen consumption was calculated. He found, as he expected, a general tendency for the oxygen consumption to increase with increasing pumping activity, whereas no consistent relation was observed between oxygen tension and oxygen consumption. Half a century later, Pritchard \& White (1981) confirmed and extended Hall's work. They found that the worm's ventilation of the tube and oxygen consumption both showed linear relations with the body pump rate (number of peristaltic waves per minute), and they estimated from their data that 30 to $48 \%$ of the total aerobic energy expenditure was used for the process of pumping.

Pritchard \& White published the regressions of $\dot{V}_{w}$ and $\dot{\mathrm{M}}_{\mathrm{O}_{2}}$ on body pump rates from which we have recalculated the relation between $\dot{\mathrm{M}}_{\mathrm{O}_{2}}$ and $\dot{\mathrm{V}}_{\mathrm{w}}$ for a $60 \mathrm{~g}$ Urechis caupo, the size of worms used by Hall. The equation is $\dot{\mathrm{M}}_{\mathrm{O}_{2}}=0.154 \dot{\mathrm{V}}_{\mathrm{w}}+11.22$, whereas Hall's data fit the equation $\dot{\mathrm{M}}_{\mathrm{O}_{2}}=0.16 \dot{\mathrm{V}}_{\mathrm{w}}+8.98$
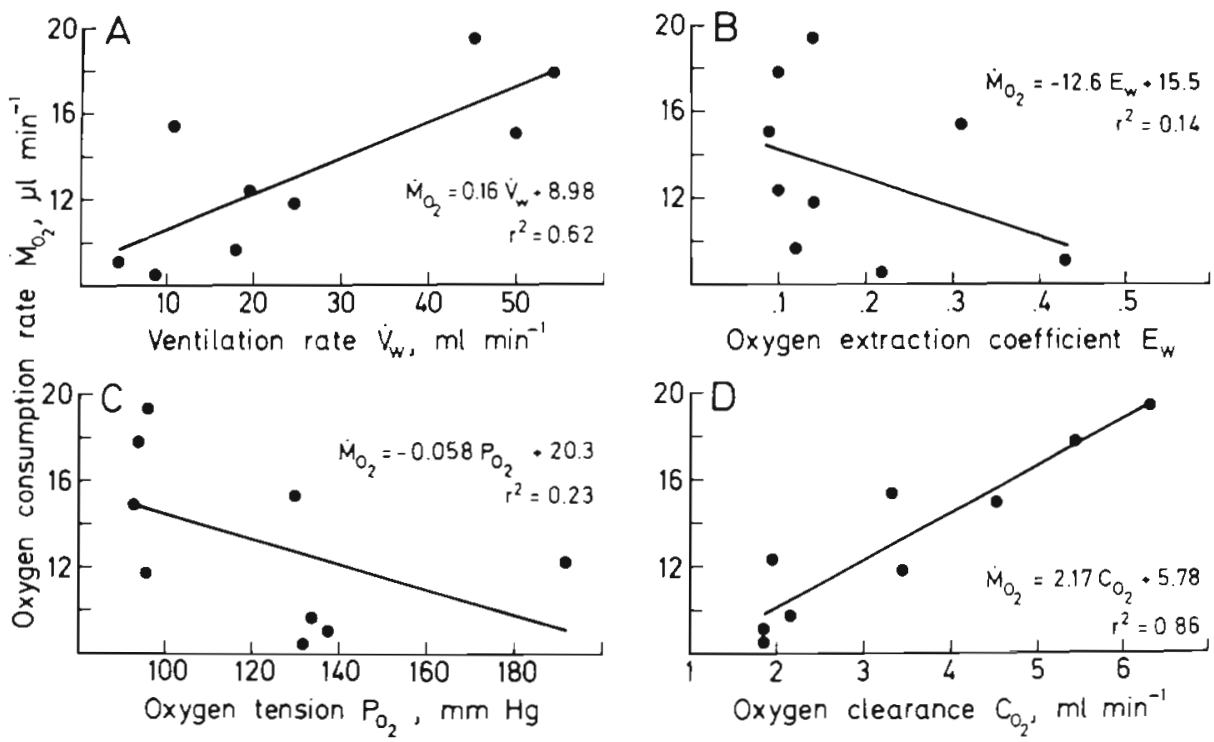

Fig. 1 Urechis caupo. Correlations between oxygen consumption $\dot{\mathrm{M}}_{\mathrm{O}_{2}}$ and (A) ventilation $\dot{\mathrm{V}}_{\mathrm{w}}$, (B) oxygen extraction $E_{w}$, (C) oxygen tension in inhalant water $\mathrm{P}_{\mathrm{O}_{2}}$, and (D) oxygen clearance $\mathrm{C}_{\mathrm{O}_{2}}=$ $\dot{V}_{w} \times E_{w}$. Based on data from Hall (1931) 
(Fig. 1). The results of Hall and of Pritchard \& White are thus in good agreement, and according to their concepts about energetic costs of ventilation the equations suggest that these costs amount to an equivalent of 0.15 to $0.16 \mu \mathrm{l}$ of $\mathrm{O}_{2}$ per ml of water pumped.

\section{Ciliary feeders}

In contrast to the scanty information on burrowdwelling filter feeders, an extensive literature deals with the relations between water processing and oxygen consumption in ciliary filter feeders, especially bivalves.

Early work suggested that in the freshwater mussel Anodonta cygnea ventilation of the mantle cavity might be regulated to meet respiratory needs (Koch \& Hers 1943). In the clam Mercenaria mercenaria, Hamwi \& Haskin (1969) found a linear relation between ventilation and oxygen consumption, and they concluded that water pumping may be at least partially regulated by oxygen requirements. Verduin (1969) reinterpreted the relation as reflecting energetic costs of the pump.

Subsequent work has been dominated by these 2 viewpoints on the cause-effect relation between $\dot{M}_{\mathrm{O}_{2}}$ and $\dot{V}_{w i}$ whether $\dot{M}_{\mathrm{O}_{2}}$ or $\dot{V}_{w}$ was the independent variable and the other the dependent variable (van Winkle 1975). A number of studies showed that $\dot{V}_{w}$ varied with $\mathrm{P}_{\mathrm{O}_{2}}$ in the ambient water, suggesting that $\dot{\mathrm{V}}_{\mathrm{w}}$ might be regulated according to the respiratory needs of the organism. Thus, Mytilus perna (Bayne 1967) and Arctica islandica, but not Mytilus edulis (Brand \& Taylor 1974, Taylor \& Brand 1975) were found to increase $\dot{V}_{w}$ at low $\mathrm{P}_{\mathrm{O}_{2}}$

Most studies only examined the respiratory responses to reduced $\mathrm{P}_{\mathrm{O}_{2}}$. It was sometimes observed that $\dot{\mathrm{M}}_{\mathrm{O}_{2}}$ remained more or less constant at declining tensions, often down to about $80 \mathrm{~mm} \mathrm{Hg}$. Below such incipient limiting tensions (Fry 1947) $\mathrm{M}_{\mathrm{O}_{2}}$ decreased with decreasing $\mathrm{P}_{\mathrm{O}_{2}}$. In other instances, $\dot{\mathrm{M}}_{\mathrm{O}_{2}}$ increased with increasing $\mathrm{P}_{\mathrm{O}_{2}}$ until air saturation of the water, at about $160 \mathrm{~mm} \mathrm{Hg}$. These 2 types of responses were interpreted as regulatory and non-regulatory responses. The apparent capacity to regulate the rate of oxygen consumption not only varied between species, but it could also depend upon the size and functional state of the individuals. Thus, freshly collected Mytilus edulis maintained high levels of oxygen consumption at declining $\mathrm{P}_{\mathrm{O}_{2}}$ down to about $80 \mathrm{~mm} \mathrm{Hg}$. When the mussels were starved in the laboratory their metabolic rate was reduced and $\dot{M}_{\mathrm{O}_{2}}$ varied linearly with $\mathrm{P}_{\mathrm{O}_{2}}$. This change in response of $\dot{\mathrm{M}}_{\mathrm{O}_{2}}$ to $\mathrm{P}_{\mathrm{O}_{2}}$ was interpreted as a change in functional response form regulation to nonregulation, and the 'regulatory' response was identified as the response of the routine or active respira- tion rate, the 'conforming' response with the standard respiration rate (Bayne 1971a, 1976, Bayne \& Newell 1983).

The concept of regulatory and conforming responses implies regulation of ventilation and/or of the blood circulation and heart rate. The heart was found to respond under various experimental conditions in ways that suggested a relation between oxygen demands and heart rate (Coleman 1974, Bayne 1976 Brand \& Morris 1984). Thus, heart rate increased with the rate of water flow through the oyster Ostrea edulis (Walne 1972), it varied with metabolic rate in Mya arenaria (Lowe \& Trueman 1972), and it responded to changes in $\mathrm{P}_{\mathrm{O}_{2}}$ in the mantle cavity water in Arctica islandica (Taylor 1976a).

Heart rates reflect rates of blood circulation, but to estimate the volume pumped per minute the stroke volume must be known. Bayne (1971b) estimated the stroke volume by observing the heart through a window cut in the shell of Mytilus edulis and measuring the dimensions of the ventricle at systole and diastole. The estimates provided minute volumes of about 0.3 to $0.7 \mathrm{ml}$ or a heart perfusion rate $\dot{\mathrm{Q}}$ of about $30 \mathrm{ml} \mathrm{h}^{-1}$.

Gas exchange in animals is characterized by the relation between ventilation and perfusion of the respiratory organs. The ratio $\dot{V}_{w} / \dot{Q}$ is typically high in water breathers compared with air breathers (Dejours et al. 1970). In fishes and various invertebrates values range from 3 to 80 (Rahn 1966, Holeton 1970, Johansen et al. 1970, Randall 1970). In Mytilus edulis the ratio can be only crudely estimated. A conservative estimate of the ventilation rate of $11 \mathrm{~h}^{-1}$ provides a $\dot{\mathrm{v}}_{\mathrm{w}} / \dot{\mathrm{Q}}$ ratio of $1000 / 30=33$.

It is of interest to look at consequences of this estimate for the role of the blood circulation in the transport of oxygen and for the role of the gills as respiratory organs. Bayne (1971b) measured extraction efficiencies of oxygen from the water of 5 to $10 \%$ at air saturation. Under these conditions the sea water contained about $6 \mathrm{ml} \mathrm{O}_{2} \mathrm{l}^{-1}$, resulting in a $\dot{\mathrm{M}}_{\mathrm{O}_{2}}$ of about $0.5 \mathrm{ml} \mathrm{h}^{-1}$ at $\mathrm{E}_{\mathrm{w}} 0.08$. This amount of oxygen consumed may be compared with the capacity of the blood in transporting oxygen to the tissues. Bivalve blood lacks a respiratory pigment, and can thus transport only physically dissolved oxygen. At saturation, a perfusion of $30 \mathrm{ml} \mathrm{h}^{-1}$ could carry $0.18 \mathrm{ml} \mathrm{O}_{2}$, thus accounting for maximally $0.18 / 0.5 \times 100=36 \%$ of $\dot{\mathrm{M}}_{\mathrm{O}_{2}}$ if $\mathrm{P}_{\mathrm{O}_{2}}$ approximates zero in the venous blood, and if the whole cardiac output passes the gills. Neither of these assumptions apply. The gill circulation represents a shunt only on the general circulation (White 1937), so the arterial blood leaving the heart is of mixed origin. It is thus suggested that only a minor part of the oxygen consumed is carried to the tissues with the circulating blood, and an even smaller part of the oxygen derives 
from uptake in the gills. This reduced role of the gills as respiratory organs would agree with the sluggish branchial circulation. Bayne (1976) cites Aiello \& Guideri (1965) for describing how contraction and relaxation of individual filaments may aid branchial circulation, but these authors note that the accordionlike movements of the interlamellar blood vessels cause the blood to shoot up the filaments during the contraction, only to wash back again during relaxation. It is difficult to imagine how such to-and-fro movements can significantly increase the efficiency of the blood circulation.

During recent years the significance of the bivalve gills and blood circulation for oxygen consumption has been more directly studied. Famme \& Kofoed (1980) demonstrated insignificance of the gills as respiratory organs by finding that excision of the gills did not affect the oxygen consumption in the artificially ventilated mussel. In Modiolus demissus, Booth \& Mangum (1978) found that ligation of the anterior aorta decreased oxygen consumption by only 10 to $15 \%$, a decline that may not be significant, or may be due to decreased ventilation. In Mytilus edulis, Famme (1981) observed no effect on the rate of oxygen uptake of artificial perfusion of the heart at rates ranging from zero to $1.36 \mathrm{ml} \mathrm{min}^{-1}$, at a constant rate of ventilation of the mantle cavity. A perfusion of $1.36 \mathrm{ml} \mathrm{min}^{-1}$ corresponds to about 3 times the minute volume as estimated by Bayne (1971b) and confirmed by Famme (1981).

In Placopecten magellanicus, Thompson et al. (1980) estimated a resting minute volume of $64 \mathrm{ml} \mathrm{h}^{-1}$, and they measured the difference in oxygen content between postbranchial and prebranchial blood to be $0.24 \mathrm{ml}$ per $100 \mathrm{ml}$ of blood, at an oxygen consumption rate of $0.4 \mathrm{ml} \mathrm{h}^{-1}$. From these data the cardiac output can be calculated to account for $38 \%$ of $\dot{\mathrm{M}}_{\mathrm{O}_{2}}$.

\section{High costs of water transport}

The demonstration that gills and even blood circulation play only small or insignificant respiratory roles in filter feeding bivalves leaves the hypothesis unsupported that variations in $\dot{\mathrm{V}}_{\mathrm{w}}$ with varying $\dot{\mathrm{M}}_{\mathrm{O}_{2}}$ represent regulation of the gill ventilation according to the respiratory needs of the organism. The second interpretation in terms of cause-effect relations between $\dot{\mathrm{M}}_{\mathrm{O}_{2}}$ and $\dot{\mathrm{V}}_{\mathrm{w}}$ implied that the increase in $\dot{\mathrm{M}}_{\mathrm{O}_{2}}$ with increasing $\dot{V}_{w}$ reflects the energetic cost of water transport (Verduin 1969). The conception that ventilation is an energetically costly process often appears in the literature, despite evidence that ciliary work is relatively inexpensive and that the energy spent on water processing in filter feeders only represents small fractions of the total metabolism (Jørgensen 1955, 1975,
Chapman 1968, Alexander 1975 p. 30, Foster-Smith 1976, Fenchel 1980, Kofoed 1980, Fenchel \& Finlay 1983). Studies that inferred high energy costs of water pumping in bivalves have been made on mussels (Newell \& Pye 1970, Thompson \& Bayne 1972, Widdows 1973, Winter \& Langton 1975, Bayne 1976, Bayne et al. 1976, Bayne \& Scullard 1977, Navarro \& Winter 1982), on oysters (Collier 1959, Newell et al. 1977), on Arctica islandica (Taylor 1976b), on the cockle Cardium edule (Newell \& Bayne 1980), and on 9 species of bivalves from the eastern coast of Canada (Bernard 1983); high costs of water processing have also been inferred in the filter feeding gastropod Crepidula fornicata (Newell \& Kofoed 1977) and in the lancelet Branchiostoma lanceolatum (Newell 1970).

Some authors realize that the high pumping costs cannot only represent work done by the water transporting cilia, and they assume that the increased metabolic costs with increased pumping rates must involve other activities as well. The relations between $\dot{\mathrm{V}}_{\mathrm{w}}$ and $\dot{\mathrm{M}}_{\mathrm{O}_{2}}$ are often studied in feeding experiments where increased filter feeding results from addition of food particles to the water. It has been suggested that part of the increase in $\dot{\mathrm{M}}_{\mathrm{O}_{2}}$ may represent the physiological cost of digestion and assimilation, often termed the 'specific dynamic action' of the food (Bayne et al. 1973, 1976, Bayne \& Scullard 1977, Newell \& Branch 1980, Navarro \& Winter 1982, Bayne \& Newell 1983, Shumway 1983). However, Griffiths \& King (1979) observed that in Aulacomya ater the $\dot{\mathrm{M}}_{\mathrm{O}_{2}}$ increased immediately with increased filter feeding. excluding 'physiological costs of feeding' to have influenced $\dot{\mathrm{M}}_{\mathrm{O}_{2}}$. Any effect of a specific dynamic action' on $\dot{\mathrm{M}}_{\mathrm{O}_{2}}$ in filter feeding remains speculative. It would have to be ascribed unrealistically high values to explain the relations observed between $\dot{\mathrm{V}}_{\mathrm{w}}$ and $\dot{\mathrm{M}}_{\mathrm{O}_{2}}$.

\section{ENERGY COSTS OF FILTER FEEDING}

Costs of filter feeding can be estimated by 2 complementary approaches. One is to estimate the work done in moving the water through the filtering structures, the other is to estimate the energy expenditures of the pump.

\section{Energy costs of water transport}

The work done in filtering the ambient water may be estimated as the product of the operating pressure of the pump and the volume of water filtered (FosterSmith 1978). Early estimates indicated that the energy expended in filter feeding amounted to at most some few per cent of the total energy expenditure of the organism (Jørgensen 1955). Estimates based on 
pressure measurements have provided values of $\leqslant 1 \%$ in the ciliary feeder Mytilus edulis (Foster-Smith 1976) and in the worms Urechis caupo (Chapman 1968) and Chaetopterus variopedatus (Brown 1977).

From determinations of the relations between volumes of water pumped and rates of oxygen consumed as well as the measurements of the pressure drops across the water-transporting structures the relative costs of water processing can be estimated in various types of filter feeders. Marine filter feeders inhabiting coastal waters typically process 151 or more of water for each $\mathrm{ml}$ of oxygen consumed (Jørgensen 1975 , Møhlenberg \& Riisgård 1979, Kiørboe et al. 1981, Riisgărd et al. 1981). The operating pressure of the gill pump, the bands of lateral cilia located just inside the entrance to the interfilamentary spaces, may amount to about $1 \mathrm{~mm} \mathrm{H}_{2} \mathrm{O}$ (C. B. Jørgensen \& B. Clemmesen unpubl.). The work done in pumping $15 \mathrm{l}$ of water at a pressure of $1 \mathrm{~mm} \mathrm{H}_{2} \mathrm{O}$ amounts to $15000 \times 0.1 \times 981$ erg $=14.7 \times 10^{5} \mathrm{erg}$, or $0.147 \mathrm{~J}$. Consumption of $1 \mathrm{ml}$ $\mathrm{O}_{2}$ generates about $5 \mathrm{cal}$ or $21 \mathrm{~J}$, the work thus corresponding to $0.7 \%$ of the total energy budget. At a mechanical efficiency of the gill pump of about $40 \%$ (Jørgensen \& Clemmesen unpubl.), the energetic cost would amount to some few per cent of the total metabolism.

The modest work represented by water-processing in filter-feeding primarily results from the pump operating at low pressures. Ciliary systems cannot produce total pressures higher than about $5 \mathrm{~mm} \mathrm{H}_{2} \mathrm{O}$. By contrast the peristaltic contractions of the body wall of Urechis caupo can produce coelomic pressures up to $100 \mathrm{~cm} \mathrm{H}_{2} \mathrm{O}$, but water is transported at low pressures of $\leqslant 1 \mathrm{~cm} \mathrm{H} \mathrm{H}_{2} \mathrm{O}$, often down to $2 \mathrm{~mm}$ (Chapman 1968). In Chaetopterus variopedatus the pump seems to operate at pressure heads of about $3 \mathrm{~mm} \mathrm{H}_{2} \mathrm{O}$ (Brown 1977). It is interesting to note that the muscular pumps work. at pressures approaching those of the ciliary pumps, suggesting that a low energetic cost of water processing represents an adaptation to the low concentrations of food in the water.

\section{REINTERPRETATION}

\section{Nature of relation between ventilation and oxygen uptake}

The seemingly paradoxical situation thus emerges that the close correlations between ventilation and oxygen consumption, as observed in several filter feeders, cannot be causally interpreted. A relation must therefore be indirect, and it may involve further parameters of the convection equation. The general convection equation reads

$$
\dot{\mathrm{M}}_{\mathrm{O}_{2}}=\dot{\mathrm{V}} \times \mathrm{E} \times \mathrm{C}_{\mathrm{IO}_{2}}
$$

where $\dot{V}=$ the ventilation, of air or water; $\mathrm{E}=$ the extraction coefficient; $\mathrm{C}_{\mathrm{IO}_{2}}=$ the oxygen concentration in the ingoing medium (Piiper et al. 1971). The convection equation is used to examine and compare gas transport in animal respiratory organs of various types, water breathers as well as air breathers, and under various conditions (Dejours 1972).

In water breathers, $\dot{\mathrm{M}}_{\mathrm{O}_{2}}$ is determined by $\dot{\mathrm{V}}_{\mathrm{w}}, \mathrm{E}_{\mathrm{w}}$ and $\mathrm{C}_{\mathrm{O}_{2}}$, In the convection equation, the product $\dot{\mathrm{V}}_{\mathrm{w}} \times \mathrm{E}_{\mathrm{w}}$ expresses the imaginary volume of water cleared of oxygen, $\mathrm{C}_{\mathrm{O}_{2}}$. Finally, the product $\dot{\mathrm{V}}_{\mathrm{w}} \times \mathrm{C}_{1 \mathrm{O}_{2}}$ equals the total amount of oxygen, $\dot{\mathrm{V}}_{\mathrm{O}_{2}}$ presented to the organism with the ventilatory current. It is, therefore, of interest to see how $\dot{M}_{\mathrm{O}_{2}}$ varies with these different parameters in filter feeders, and how the relations obtaining between them can be interpreted. Such examinations were made in Urechis caupo and in Mytilus edulis.

\section{Urechis caupo}

The convection equation could be applied to Hall's (1931) data from Urechis caupo. Fig. 1 shows that $\dot{\mathrm{M}}_{\mathrm{O}_{2}}$ was correlated with $\dot{V}_{w}$, but hardly with $\mathrm{E}_{\mathrm{w}}$ or $\mathrm{C}_{\mathrm{lO}_{2}}$, expressed as the oxygen tension, $\mathrm{P}_{\mathrm{O}_{2}}$. The degree of correlation between $\dot{\mathrm{M}}_{\mathrm{O}_{2}}$ and $\dot{\mathrm{V}}_{\mathrm{O}_{2}}$ was similar to that observed between $\dot{\mathrm{M}}_{\mathrm{O}_{2}}$ and $\dot{\mathrm{V}}_{\mathrm{w}} \mathrm{r}^{2}$ being 0.55 in the former and 0.62 in the latter relation. Substitution of ventilation by total amount of oxygen presented, therefore, did not influence the correlation with oxygen uptake. This is in contrast to the correlation between $\dot{\mathrm{M}}_{\mathrm{O}_{2}}$ and the other derived parameter, $\mathrm{C}_{\mathrm{O}_{2}}$, which correlation was higher than any of the others observed, $\mathrm{r}^{2}$ being 0.86 . This relatively high correlation between oxygen uptake and the imaginary volume expressed by the clearance of oxygen suggests that not all oxygen in the ventilatory current is available to $U$. caupo and that $\mathrm{C}_{\mathrm{O}_{2}}$ reflects the 'availability' of the oxygen.

All arguments concerning causal relations between $\dot{\mathrm{M}}_{\mathrm{O}_{2}}$ and $\dot{\mathrm{V}}_{\mathrm{w}}$ have tacitly implied that the oxygen in the ventilatory current was uniformly available to the pumping organism, disregarding the fluid mechanical properties of the pump. These properties are reflected in the Reynolds number as determined by dimension and velocity of the currents.

The rate of water pumping is given by the stroke volume times frequency of pumping events, that is, number of peristaltic waves passing along the body (Fig. 3A). The stroke volume is determined by the distance between tube wall and surface of the constricted part of the body as well as the wave length, the distance between 2 subsequent peristaltic waves. The stroke volume may, therefore, be determined as the 


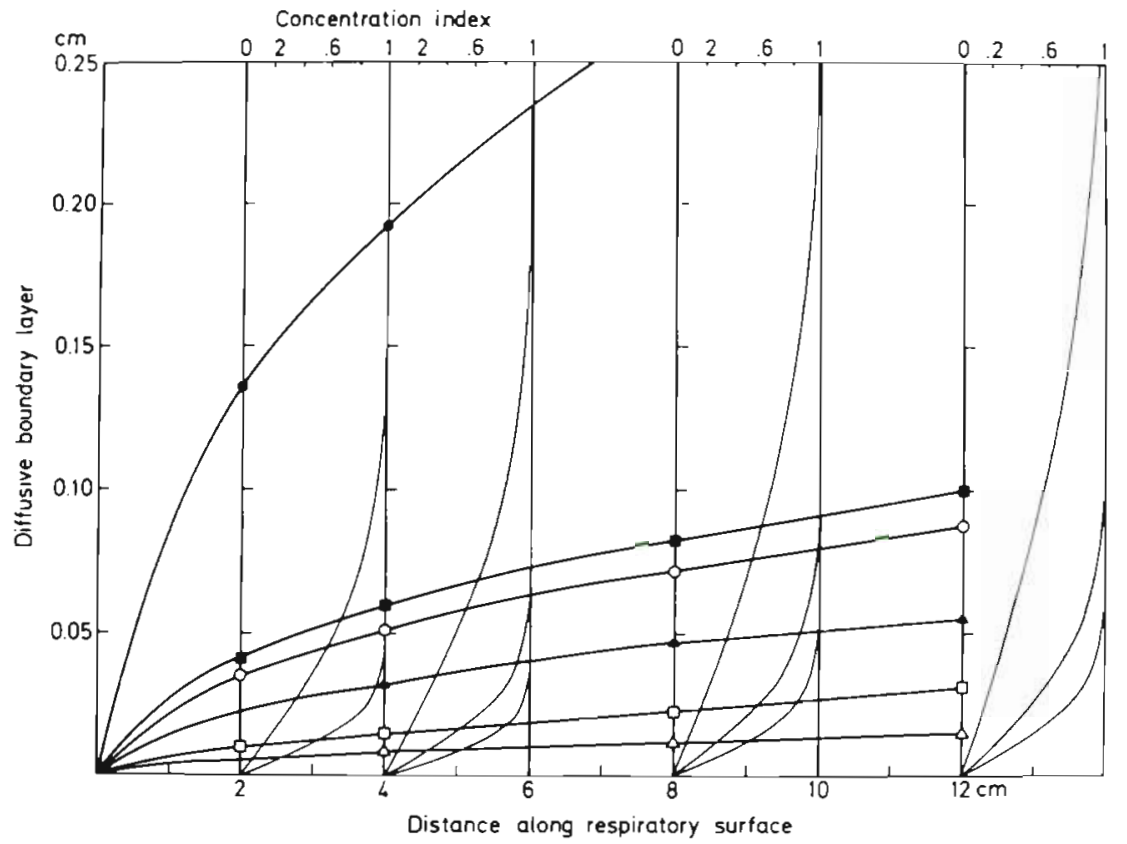

Fig. 2. Construction of oxygen isopleths within a ventilatory current passing a respiratory surface, based on diffusive oxygen profiles established as function of flow velocity. Open symbols represent isopleths corresponding to halving of the concentration in the bulk flow, $\delta_{0.5}$. Closed symbols indicate transitions from the diffusive boundary layer to ambient oxygen concentration, represented by the $\delta_{0.99}$ isopleth. Flow velocities in $\mathrm{cm}$ $\mathrm{s}^{-1}$ are $(0, \bullet) 0.029,(\square, \bullet) 0.31$, and $(\Delta, \Delta)$ 1.00 volume of the circular mantle of water surrounding the constricted part of the body and forced down the tube by the piston-like inflated part of the body, assuming minimal back-flow of water (Chapman 1968).

The minute volume of the pump, $\dot{V}_{w}$, is equal to the cross sectional area of the current times the flow velocity, $v$. This velocity is equal to frequency of peristaltic waves, $f$, times wave length, $\lambda$.

The elements that determine the characteristics of the pump appear reasonably well defined, but uncertainty prevails about the absolute dimensions to be used in calculating capacities. Presumably, the ventilation $\dot{V}_{w}$ is especially sensitive to the distance between body surface and tube wall, which determines the cross sectional area of the ventilatory current. This distance depends upon the degree of constriction of the body, the variation of which remains to be ascertained.

Jørgensen (1955) estimated the ventilation in Urechis caupo acclimated whithin glass tubes to the running sea water of the Kerckhoff Marine Station, Corona del Mar, California. Measurements were made on a $21 \mathrm{~g} U$. caupo accomodated in a glass tube of $2.5 \mathrm{~cm}$ internal diameter, which is close to the dimensions of the normal burrow. The diameter of the constricted part was determined to be about $1.3 \mathrm{~cm}$, f was 8 to $9 \mathrm{~min}^{-1}$, and $\lambda$ corresponded to the length of the worm of about $10 \mathrm{~cm}$. From these data the cross sectional area of the current amounts to $\pi\left(1.25^{2}-0.65^{2}\right)=$ $3.58 \mathrm{~cm}^{2}$, whereas $\mathrm{v}=\mathrm{f} \times \lambda=85 \mathrm{~cm} \mathrm{~min}^{-1}$. To arrive at a more accurate estimate of the minute volume, $\lambda$ should be corrected for the part of the stroke volume occupied by the inflated part of the body. The effective $\lambda$ is thus about $10-3=7 \mathrm{~cm}, \dot{V}_{\mathrm{w}}$ is $213 \mathrm{ml} \mathrm{min}^{-1}$, and the stroke volume is $25 \mathrm{ml}$.

Fig. 2 in Pritchard \& White (1981) suggests that in a $17 \mathrm{~cm}$ Urechis caupo, weighing about $60 \mathrm{~g}$ and accommodated in a $2.5 \mathrm{~cm}$ glass tube, the diameter of the constricted part is about $1.7 \mathrm{~cm}$ providing a cross sectional area of the ventilation current of $2.64 \mathrm{~cm}^{2}$. The frequency of peristaltic waves varied between about 3 and $11 \mathrm{~min}^{-1}$, the last value predominating at $22^{\circ} \mathrm{C}$. $\lambda$ is not well defined but seemed to approximate half the body length, or $8 \mathrm{~cm}$. If we correct for the thickness of the piston, the effective wave length may be about $5 \mathrm{~cm}$, and $\dot{V}_{w}$ may be calculated as $2.64 \times 11 \times 5=145 \mathrm{ml} \mathrm{min}^{-1}$, the stroke volume being $13 \mathrm{ml}$. Measurements of $\dot{\mathrm{V}}_{\mathrm{w}}$ as a function of $\mathrm{f}$ (Pritchard \& White 1981, Fig. 7) indicated stroke volumes as low as about $8 \mathrm{ml}$.

Future investigations must clarify the discrepancies between calculated and measured values of $\dot{V}_{w}$ and stroke volumes in Urechis caupo. The variation in pumping rates, however, does not significantly affect the fluid mechanical properties of the U. caupo pump, as indicated by the Reynolds number. The Reynolds number may be estimated from the thickness of the water layer passing between the body surface and the wall of the tube, $h$, and the velocity of the current, $v$, according to the relation $\operatorname{Re}=\mathrm{h} \times \mathrm{v} / \mathrm{v}$, where $v$ is the kinematic viscosity (Vogel 1981). At $\mathrm{h}=0.4 \mathrm{~cm}, \mathrm{v}=$ $1 \mathrm{~cm} \mathrm{~s}^{-1}$, and $v=10^{-2} \mathrm{~cm}^{2} \mathrm{~s}^{-1}$; Re amounts to 40 , implying that the flow of water through the $U$. caupo tube is laminar. The threshold for turbulent flow is at Re numbers around 2000.

The laminar flow pattern of the ventilatory current 
implies that the oxygen in the passing water is available to Urechis caupo only by diffusion. The uptake of oxygen will establish a diffusive boundary layer at the interface between the ventilatory current and the body surface through which oxygen is taken up. Three approaches were used for estimating the thickness of the diffusive boundary layer $\delta$.

Theoretical approach. When the ventilatory current reaches the anterior end of the worm oxygen begins to diffuse from the water into the respiring tissue. As the enveloping mantle of water passes down the surface of the worm concentration gradients of oxygen evolve normal to the interface. The pattern of this diffusion layer is determined by the flow velocity and the diffusion coefficient $D$ of oxygen in water. This pattern could be approached by calculations of the oxygen profiles along the surface as a function of the flow velocity (see 'Appendix'). From the data obtained it was possible to construct the corresponding oxygen isopleths within the ventilatory current passing the respiratory surface. Examples of the construction of such isopleths are shown in Fig. 2. It may be seen that at a velocity of $1 \mathrm{~cm} \mathrm{~s}^{-1}$ the isopleth corresponding to a halving of the oxygen gradient between the interphase and the bulk phase $4 \mathrm{~cm}$ down the respiratory surface was situated $0.008 \mathrm{~cm}$ above the surface, $\delta_{0.5}$ having increased to $0.015 \mathrm{~cm}$ above the surface when the $12 \mathrm{~cm}$ level was reached. The delimitation between the diffusive boundary layer and the bulk phase, as defined by the isopleth $\delta_{0.99}$, indicating a $1 \%$ reduction of the oxygen gradient, was $0.032 \mathrm{~cm}$ above the surface $4 \mathrm{~cm}$ down and $0.055 \mathrm{~cm} 12 \mathrm{~cm}$ down the respiratory surface. These values for the thickness of the diffusive boundary layer correspond to the flow rate calculated by Jørgensen (1955). Fig. 2 also gives

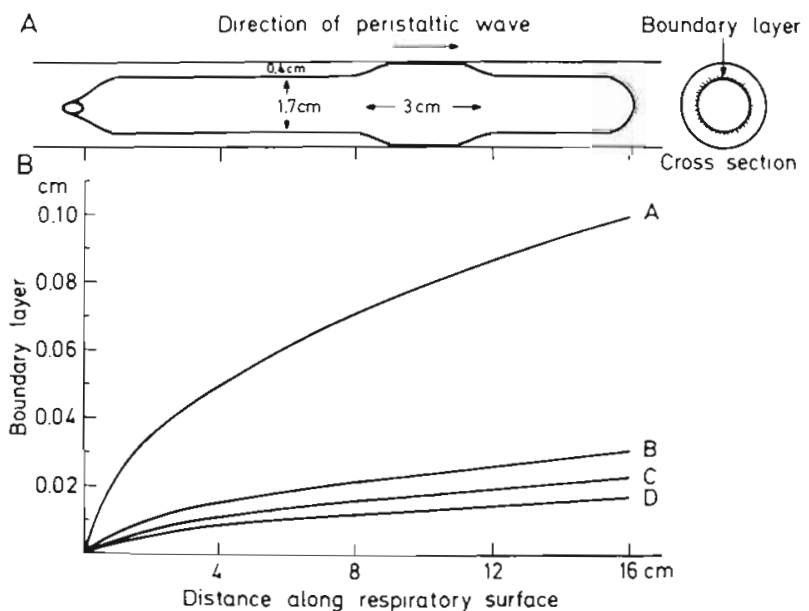

Fig. 3. Urechis caupo. (A) Diagram of worm ventilating the tube. (B) Increases in the thickness of the diffusive boundary layer $\delta$ established by the oxygen uptake along the tube, at varying transit times, $t$, of the ventilation examples of $\delta_{0.5}$ and $\delta_{0.99}$ isopleths constructed for the much lower ventilatory currents recorded by Hall (1931). Fig. $3 B$ shows the $\delta_{0.5}$ isopleths along a $16 \mathrm{~cm}$ long Urechis caupo ventilating at rates as recorded by Hall (1931), Lawry (1966) and Jørgensen (1955). The time taken for the respiratory current to pass the worm, the transit time, varied from 550 to $16 \mathrm{~s}$. The thickness of the diffusive boundary layer established increased linearly with the square root of the transit time (see 'Appendix').

Fick's equation. An estimate of the value of $\delta$ may also be obtained from the measured rates of oxygen uptake, assuming diffusion to take place across the epidermis according to Fick's equation

$$
\mathrm{J}=\mathrm{D} \Delta\left[\mathrm{O}_{2}\right] / \delta
$$

where $\mathrm{J}=$ rate of oxygen diffusion per unit area and unit time; $\Delta\left[\mathrm{O}_{2}\right]=$ the oxygen gradient between the bulk phase and the interphase. $J$ equals $\dot{M}_{\mathrm{O}_{2}}$ divided by the surface area, $A$, across which oxygen diffuses. The thickness of the diffusive boundary layer may thus be estimated from

$$
\delta=\mathrm{D} \Delta\left[\mathrm{O}_{2}\right] \times \mathrm{A} / \dot{\mathrm{M}}_{\mathrm{O}_{2}}
$$

Pritchard \& White (1981) found the difference between oxygen tension in the ambient water and the coelomic fluid to be about $35 \mathrm{~mm} \mathrm{Hg}$ over a wide range of ambient $\mathrm{P}_{\mathrm{O}_{2}}$ values, corresponding to a $\Delta\left[\mathrm{O}_{2}\right]$ of about $1.25 \mu \mathrm{O}_{2} \mathrm{~cm}^{-3}$. The exposed smooth surface area of a $16 \mathrm{~cm}$ Urechis caupo was estimated to be $80 \mathrm{~cm}^{2}$. At rates of oxygen consumption of 0.25 to $0.30 \mu \mathrm{l} \mathrm{s} \mathrm{s}^{-1}$ (Hall 1931, Pritchard \& White 1981) a $\delta$ value of $0.006 \mathrm{~cm}$ can be calculated. This may be an underestimate of the actual value, because the surface of $U$. caupo is rugose and papillate (Lawry 1966), and the available area may thus be substantially larger than assumed in the calculation.

Oxygen clearance. The thickness of the diffusive boundary layer was finally estimated from the volume of oxygen cleared, as given by the convection equation. At a $\dot{\mathrm{M}}_{\mathrm{O}_{2}}$ value of about $0.30 \mu \mathrm{l} \mathrm{s} \mathrm{s}^{-1}$ and an oxygen content of $6 \mu \mathrm{ml}^{-1}$ in the bulk flow, the volume cleared is about $0.05 \mathrm{~cm}^{3} \mathrm{~s}^{-1}$. If a peristaltic wave transports this volume of water along the surface of the animal at a velocity of $1 \mathrm{~cm} \mathrm{~s}^{-1}$ the thickness of the layer is determined by the circumference of the constricted part of the body, or $\pi \times 1.7=5.3 \mathrm{~cm}$. The operative thickness, $h$, of the layer of water cleared

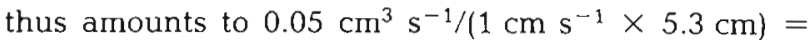
$0.0094 \mathrm{~cm}$.

These different approaches to estimate the thickness of the diffusive boundary layer in Urechis caupo thus provide results in substantial agreement, estimated $\delta$ values amounting to about one tenth of a $\mathrm{mm}$. This thickness should be compared with the thickness of 


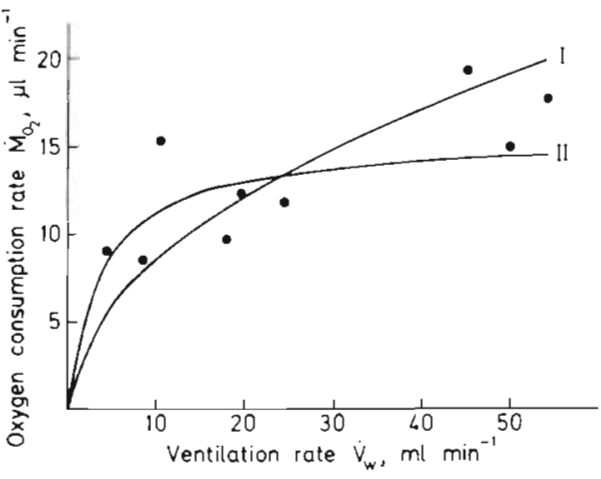

Fig. 4. Urechis caupo. Reinterpretation of Hall's (1931) data on relation between ventilation and oxygen consumption. Curve I reflects oxygen consumption being inversely proportional to $\delta$, and $\delta$ proportional to the square root of the transit time, $t^{1 / 2}$. Curve II interprets the data in terms of MichaelisMenten kinetics. See text for further explanation

about $4 \mathrm{~mm}$ of the laminar current passing the body. It is noteworthy that even at the lowest flow velocity the boundary layer reaches less than half the distance from the body surface to the wall to the tube (Fig. 3). Presumably, the larger fraction of the dissolved oxygen in the ventilatory current $\dot{\mathrm{V}}_{\mathrm{O}_{2}}$ is, therefore, unavailable to the worm for consumption by molecular diffusion.

Interpretation of correlations between ventilation and oxygen consumption in Urechis caupo in terms of energetic costs of water pumping seems unreconcilable with the laminar pattern of flow through the tube. It is, therefore, of interest to see whether the connected data on oxygen consumption and water pumping can be interpreted in other terms. The data are replotted in Fig. 4 , and 2 curves are indicated, both originating at zero. Curve I represents a fit that reflects the thickness of the diffusive boundary layer, $\delta$, being proportional to the square root of the transit time whereas $\mathrm{J}$ (and thus $\dot{\mathrm{M}}_{\mathrm{O}_{2}}$ ) is inversely proportional to $\delta$. At low rates of ventilation the oxygen consumption is presumably limited by the supply, and $\dot{\mathrm{M}}_{\mathrm{O}_{2}}$ should initially rise relatively steeply according to the relation indicated by the curve. As long as oxygen availability alone determines the consumption, the relations between $\dot{V}_{w}$ and $\dot{\mathrm{M}}_{\mathrm{O}_{2}}$ depicted by curve I should apply. It seems likely though that above certain threshold ventilatory rates, $\dot{\mathrm{M}}_{\mathrm{O}_{2}}$ will more and more reflect the metabolic capacity of the $U$. caupo organism, and therefore satiation relations should develop between $\dot{\mathrm{V}}_{\mathrm{w}}$ and $\dot{\mathrm{M}}_{\mathrm{O}_{2}}$. Curve II describes satiation relations as a hyperbolic function in terms of Michaelis-Menten kinetics. $\dot{\mathrm{M}}_{\mathrm{O}_{2}}$ max was found to be $15.6 \mu \mathrm{min}^{-1}$, and the half satura-

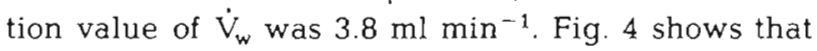
both types of relation provide equally good, or bad, fits, correlated with the great scatter in the data available. Further studies are needed to elucidate the relations between $\dot{\mathrm{V}}_{\mathrm{w}}$ and $\dot{\mathrm{M}}_{\mathrm{O}_{2}}$ in Urechis caupo, and to assess the relative importance of diffusive and metabolic capacities in determining oxygen consumption.

\section{Mytilus edulis}

In Urechis caupo, the relations between oxygen consumption and ventilation were incompletely defined because of uncertainty about normal rates of ventilation. Rates of undisturbed water processing are well established in several other groups of filter feeders, including Mytilus edulis in which Famme \& Kofoed (1980) studied the relations between ventilation, oxygen tension, and oxygen consumption. The relations were compared in naturally ventilating and in artificially ventilated mussels. The mantle cavity was perfused using a micro centrifugal pump with the outlet tubing inserted into the inhalant aperture. Experiments were made on $7 \mathrm{~cm}$ long mussels.

The relations between oxygen tension and oxygen uptake in the artificially ventilated mussels could be fitted by rectangular hyperbola, and the relations could be described by equations of the MichaelisMenten type, such as $\mathrm{R}=\mathrm{Rm} \times \mathrm{x} /(\mathrm{Ku}+\mathrm{x})$, where $\mathrm{Rm}$ is the maximum rate of oxygen uptake and $\mathrm{Ku}$ is the oxygen concentration ( $=$ oxygen tension) at which half
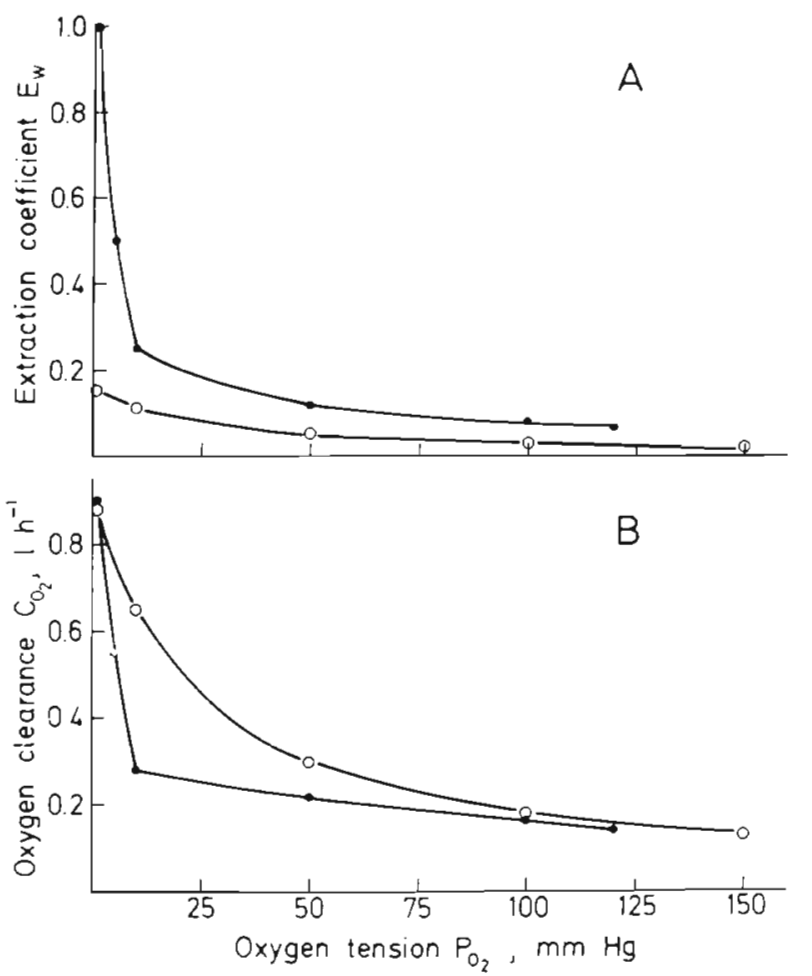

Fig. 5. Mytilus edulis. Relations between oxygen tension in inhalant water and (A) oxygen extraction and (B) oxygen clearance in a $7 \mathrm{~cm}$ mussel when (-) naturally ventilating and (O) artificially perfused. Based on data from Famme \& Kofoed (1980) 
the maximum rate is reached. The removal of oxygen from the water passing the mantle cavity may be expressed as a volume of water cleared of oxygen, calculated as $\mathrm{R} / \mathrm{x}=\mathrm{Rm} \times \mathrm{x} /[(\mathrm{Ku}+\mathrm{x}) \mathrm{x}]=\mathrm{Rm} /(\mathrm{Ku}+$ x) (Fenchel 1982). Oxygen clearance $\mathrm{C}_{\mathrm{O}_{2}}$ increases with decreasing concentration of oxygen to approach $\mathrm{Rm} / \mathrm{Ku}$ when $\mathrm{x}$ becomes $<<\mathrm{Ku}$. $\mathrm{C}_{\mathrm{O}_{2} \max }$ may, therefore, be calculated as $\mathrm{Rm} / \mathrm{Ku}$. Finally, the maximum extraction of oxygen $E_{\text {wmax }}$ could be calculated as the ratio between maximal clearance and perfusion rate, $\mathrm{C}_{\mathrm{O}_{2} \mathrm{max}} / \dot{\mathrm{V}}_{\mathrm{w}}$

In the normally ventilating mussel the relations between oxygen uptake and oxygen tension could not be described in terms of Michaelis-Menten parameters, but the relations between $\mathrm{P}_{\mathrm{O}_{2}}\left(\sim \mathrm{C}_{\mathrm{O}_{2}}\right)$ and the other parameters of the convection equation, $\dot{\mathrm{M}}_{\mathrm{O}_{2}} \dot{\mathrm{V}}_{\mathrm{w}}$, and $E_{w}$, could be read from graphs (Famme \& Kofoed 1980 Fig. 2, 3 \& 4).

Naturally ventilating and artificially perfused mussels exhibited significant differences in the extraction and clearance of oxygen. Fig. 5 shows oxygen extraction and clearance in the same mussel, when naturally ventilating and when perfused at a rate of $5.6 \mathrm{l} \mathrm{h}^{-1}$, as a function of the oxygen tension in the ambient water. It may be seen (Fig. $5 \mathrm{~A}$ ) that with decreasing $\mathrm{P}_{\mathrm{O}_{2}}$, down to values below $50 \mathrm{~mm} \mathrm{Hg}$, the extraction of oxygen increased slowly. At $10 \mathrm{~mm} \mathrm{Hg}$ the extraction was
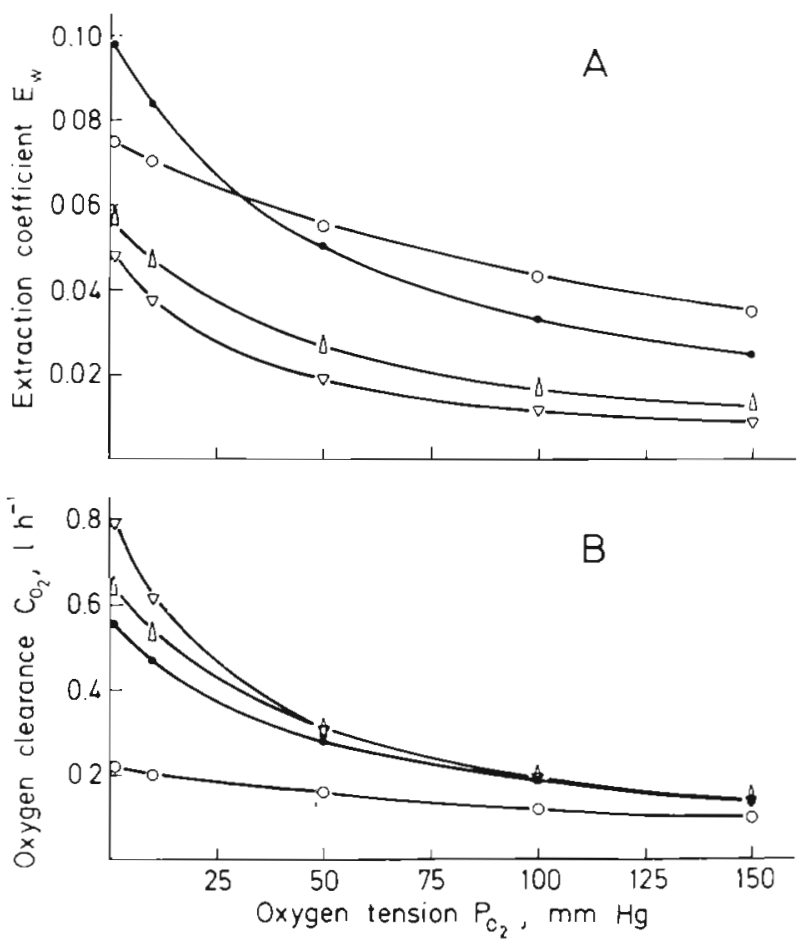

Fig. 6. Mytilus edulis. Relations between oxygen tension in inhalant water and (A) oxygen extraction and (B) oxygen clearance in perfused mussels. Perfusion rates: (O) $2.9 \mathrm{l} \mathrm{h}^{-1}$; (•) $5.6 \mathrm{l} \mathrm{h}^{-1} ;(\Delta) 11.3 \mathrm{l} \mathrm{h}-1 ;(\nabla) 16.4 \mathrm{l} \mathrm{h}^{-1}$. Based on data from Famme \& Kofoed (1980)
Table 1 Mytilus edulis. Kinetics of oxygen uptake in artificially perfused mussels. Mussels $7 \mathrm{~cm}$ long, wet weight of soft tissues about $7 \mathrm{~g}$. Salinity $17.1 \%$, temp. $10.8^{\circ} \mathrm{C}$, range of $\mathrm{P}_{\mathrm{O}_{2}}$ 160 to $\sim 0 \mathrm{~mm} \mathrm{Hg}\left(1 \mathrm{~mm} \mathrm{Hg} \sim 0.044 \mathrm{ml} \mathrm{O}_{2} \mathrm{1}^{-1}\right)$. (Based on Famme \& Kofoed 1980)

\begin{tabular}{|ccccc|}
\hline $\begin{array}{l}\text { Experimental } \\
\text { condition }\end{array}$ & $\begin{array}{c}\mathrm{Rm} \\
\mathrm{ml} \mathrm{O}_{2} \mathrm{~h}^{-1}\end{array}$ & $\begin{array}{c}\mathrm{Ku} \\
\mathrm{ml} \mathrm{O}_{2} \mathrm{l}^{-1}\end{array}$ & $\begin{array}{c}\mathrm{C}_{\mathrm{O}_{2 m a x}} \\
\mathrm{Rm}^{\mathrm{K} u} \\
1 \mathrm{~h}^{-1}\end{array}$ & $\begin{array}{c}\mathrm{E}_{\text {wmax }}= \\
\mathrm{C}_{\mathrm{O}_{\text {2max }}} / \dot{\mathrm{V}}_{\mathrm{w}}\end{array}$ \\
\hline $\begin{array}{l}\text { Perfusion rate } \\
\left(\mathrm{l} \mathrm{h}^{-1}\right)\end{array}$ & & & & \\
2.9 & 1.27 & 5.81 & 0.22 & 0.075 \\
5.6 & 1.23 & 2.18 & 0.56 & 0.100 \\
11.3 & 1.22 & 1.86 & 0.66 & 0.058 \\
16.4 & 1.12 & 1.38 & 0.81 & 0.049 \\
Gills & & & & \\
Intact & 0.6 & 1.13 & 0.53 & 0.095 \\
Excised & 0.6 & 1.32 & 0.45 & 0.080 \\
\hline
\end{tabular}

about 0.1 in the perfused state, and about 0.25 in the ventilating state. Below oxygen tensions of $10 \mathrm{~mm} \mathrm{Hg}$ the extraction rose steeply in the ventilating mussel, to approach 1.0 as the water became depleted of oxygen, whereas extraction approached only about 0.15 in the perfused mussel. The relations between $\mathrm{P}_{\mathrm{O}_{2}}$ and oxygen clearance is shown in Fig. 5 B. At saturation values the mussel cleared equal volumes independently of the ventilatory type. With decreasing oxygen tension the $\mathrm{C}_{\mathrm{O}_{2}}$ increased gradually in the perfused mussels, whereas in the ventilating mussel the increase was slow down to a $\mathrm{P}_{\mathrm{O}_{2}}$ of about $10 \mathrm{~mm} \mathrm{Hg}$ and then rose steeply.

The effects of perfusion rate on extraction and clearance of oxygen are shown in Fig. 6 and Table 1 Oxygen extraction declined regularly with increasing perfusion, whereas oxygen clearance became independent of perfusion rate and oxygen tension at $\dot{\mathrm{V}}_{\mathrm{w}} \geqslant 5.6 \mathrm{l} \mathrm{h}^{-1}$ and $\mathrm{P}_{\mathrm{O}_{2}} \geqslant 75 \mathrm{~mm} \mathrm{Hg}$. The maximal extraction of oxygen at $\mathrm{P}_{\mathrm{O}_{2}}$ approaching zero was $10 \%$, at $\dot{V}_{\mathrm{w}}=5.6 \mathrm{I} \mathrm{h}^{-1}$ (Table 1 ).

It thus seems a basic difference in the relations between $\dot{V}_{w}$ and $\dot{M}_{\mathrm{O}_{2}}$ that all oxygen in the water flowing through the mantle cavity is potentially available to the naturally ventilating mussel, whereas only a fraction of the oxygen is available to the artificially ventilated mussel. The flow characteristics of the 2 types of ventilations must, therefore, differ.

\section{Laminar flow and dirfusive oxygen uptake}

To further elucidate the relations between the flow rates through the mantle cavity and the rates of oxygen uptake, and especially the different patterns observed in perfused and ventilating mussels, the characteristics 


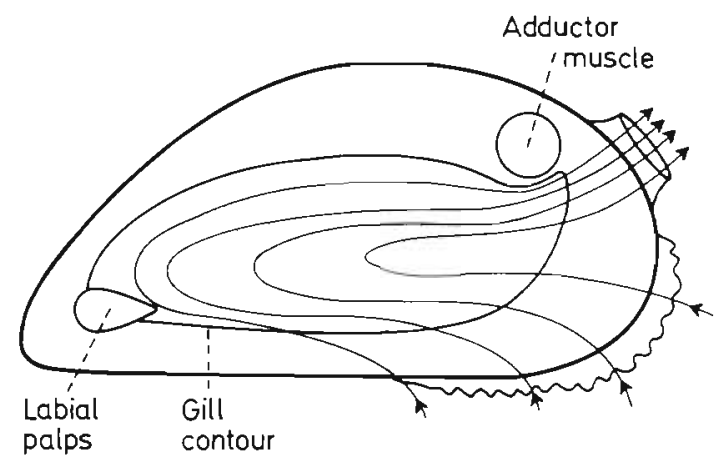

Fig. 7. Mytilus edulis. Diagram of ventilatory current passing through the mantle cavity in mussel with extended mantle edges and exhalant siphon

of the flow were established from dimensions and velocities of the through currents. Measurements on 14 specimens of Mytilus edulis showed that at a length of $7.0 \mathrm{~cm}$, the mean height was about $3.4 \mathrm{~cm}$ and the mean width was about $3.2 \mathrm{~cm}$. The height of the mantle cavity is reduced by the dorsally placed body mass, and both height and width of the mantle cavity diminishes anteriorly and posteriorly. Assuming an approximate ellipsoidal cross section with a mean height of $2.8 \mathrm{~cm}$ and a mean width of $2.0 \mathrm{~cm}$, we arrive at a mean cross sectional area of the mantle cavity of $4.4 \mathrm{~cm}^{2}$ in a $7 \mathrm{~cm}$ long mussel. The patterns of flow through the mantle cavity of the mussel is presumably less well-defined than that through the tube of Urechis caupo because of the irregular shape of the mantle cavity. However, the nature of the pump driving the water may tend to reduce variation in flow patterns. The driving force of the flow is the system of bands of lateral cilia arranged in parallel in the interfilamentary spaces of the 4 demibranchs which subdivide the mantle cavity longitudinally into an infrabranchial and a suprabranchial cavity. Because of the uniform array of identical gill pumps the ventilatory current may be diverted toward the entire gill surface to produce a relatively homogeneous flow through the mantle cavity, as indicated in the diagram in Fig. 7 , characterized by a mean flow velocity. At a ventilation of $16.41 \mathrm{~h}^{-1}$, or $4.6 \mathrm{~cm}^{3} \mathrm{~s}^{-1}$, corresponding to the highest perfusion used (Famme \& Kofoed 1980) or to undisturbed ventilation (Møhlenberg \& Riisgård 1979), the velocity at a cross sectional area of $4.4 \mathrm{~cm}^{2}$ is approximately $1.0 \mathrm{~cm}$ $\mathrm{s}^{-1}$. The mantle cavity is subdivided into compartments by the gills, so that the thickness of the ventilatory currents presumably nowhere exceeds $1 \mathrm{~cm}$, providing Reynolds numbers of $\leqslant 100$. Flow through the mantle cavity is thus laminar, and oxygen is available to the mussel only by diffusion, the rate of oxygen consumption being related to the thickness of the diffusive boundary layer $\delta$ established at the interface between the ventilatory current and the surfaces of mantle and gills.

As mentioned, the gills in the perfused Mytilus edulis did not contribute significantly to oxygen uptake above threshold values of $\dot{\mathrm{V}}_{\mathrm{w}}$ and $\mathrm{P}_{\mathrm{O}_{2}}$ (Famme \& Kofoed 1980). It was, therefore, of interest to assess the diffusive capacity for oxygen uptake through the undifferentiated epidermis of the mantle cavity, applying the approaches adopted for Urechis caupo. This includes knowing, besides the velocity of flow, the oxygen gradient between the bulk phase and the interphase, and the dimensions of the respiratory surface.

The oxygen gradient can be estimated from the oxygen tension in the hemolymph. Famme (1981) measured $\mathrm{P}_{\mathrm{O}_{2}}$ values in the mussel heart that were about $50 \mathrm{~mm} \mathrm{Hg}$ below the external $\mathrm{P}_{\mathrm{O}^{\prime}}$, corresponding to an

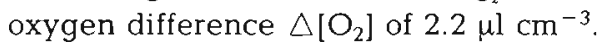

The surface area of the mantle cavity in the ventilating mussel was estimated to $55 \mathrm{~cm}^{2}$, using the formula for the area of a prolate spheroid $=2 \pi \mathrm{b}^{2}+2 \pi \mathrm{ab} / \varepsilon$ $\sin ^{-1} \varepsilon$, with the long axis $2 \mathrm{a}=7.0$ and the short axes $2 \mathrm{~b}=3 \mathrm{~cm}$. The mean pathway of the ventilatory current may be estimated from the flow velocity and the turnover time of water enclosed within the mantle with edges and exhalant siphon extended. The volume of the mantle cavity was estimated to $33 \mathrm{~cm}^{3}$, using the formula for the volume of a prolate spheroid $=4 / 3 \pi a b^{2}$. This volume agrees with the volume of about $23 \mathrm{~cm}^{3}$ measured by Famme (1980a) in the closed $7 \mathrm{~cm}$ long mussel. At an optimal ventilation of $4.6 \mathrm{~cm}^{3} \mathrm{~s}^{-1}$ the turnover time amounts to $33 \mathrm{~cm}^{3} / 4.6 \mathrm{~cm}^{3} \mathrm{~s}^{-1}=7 \mathrm{~s}$, and the pathway amounts to $7 \mathrm{~s} \times 1 \mathrm{~cm} \mathrm{~s}^{-1}=7 \mathrm{~cm}$. The mean path length of the through current is thus of the same magnitude as the length of the mussel, as also indicated from the diagram in Fig. 7.

The model used for calculation of oxygen profiles along the respiratory surface of Urechis caupo also applies to the respiratory pathway represented by the mantle surface in the mussel. By inserting the values for optimal flow velocity and length of pathway the $\delta_{0.5}$ amounted to $0.011 \mathrm{crn}$ when the current reached the end of the respiratory pathway (Fig. 2).

The estimate of the thickness of the diffusive boundary layer from Fick's equation, as calculated from Equation (2), amounted to $0.008 \mathrm{~cm}$, at a rate of oxygen uptake of $0.30 \mu \mathrm{l} \mathrm{s}^{-1}$ (Famme \& Kofoed 1980).

The thickness of the diffusive boundary layer can be only roughly estimated from the volume of oxygen cleared because a well-defined circumference of the oxygen absorbing surface is lacking. If we assume a geometry corresponding to a cylinder of length equal to the distance travelled through the mantle cavity, the circumference of the flow is $7.9 \mathrm{~cm}$. At an oxygen clearance of $0.14 \mathrm{l} \mathrm{h}^{-1}$, or $0.04 \mathrm{~cm}^{3} \mathrm{~s}^{-1}$, and a flow 
velocity of $1 \mathrm{~cm} \mathrm{~s}^{-1}$, the operative thickness of the layer of water cleared amounts to $0.04 \mathrm{~cm}^{3} \mathrm{~s}^{-1 /(1 \mathrm{~cm}}$ $\left.\mathrm{s}^{-1} \times 7.9 \mathrm{~cm}\right)=0.0051 \mathrm{~cm}$.

The 3 approaches to an estimate of the thickness of the diffusive boundary layer, assuming oxygen to be taken up exclusively through the undifferentiated surface of the mantle cavity, are thus in substantial agreement. Moreover, they agree with the estimates of $\delta$ obtained in Urechis caupo. As in U. caupo, the diffusive boundary layer is thin compared with the thickness of the mantle currents, stressing the unavallability of the greater part of the oxygen present in the current.

It is noteworthy that the estimated $\delta$ values in Urechis caupo and Mytilus edulis are of the same magnitude as diffusive boundary layers directly measured by means of oxygen microelectrodes at the interface between the water and respiring surfaces of sediments or detritus (Jørgensen \& Revsbech 1984, Revsbech \& Jørgensen 1985).

\section{$E_{w}$ in naturally ventilating and artificially ventilated mussels}

As mentioned, the relation between oxygen tension and oxygen extraction and clearance showed characteristic differences between the naturally ventilating and the artificially ventilated mussel (Fig. 6, Table 1). Such differences in pattern were to be expected. In well-oxygenated water the oxygen consumption measured approximated the uptake calculated from diffusion across the general mantle surface. Thus uptake through the gills was negligible. However, in oxygen depleted water the rate of uptake of oxygen decreases rapidly with the decreasing capacities of the diffusional pathways and the diffusional uptake across the surfaces exposed to the mantle cavity becomes insignificant except across the surfaces of the gill filaments (Fig. 8). In the about $40 \mu \mathrm{m}$ broad interfilamentary spaces the ventilatory current is brought within distances of the interface about an order of magnitude smaller than the thickness of the diffusive boundary layer, implying that all oxygen in the ventilatory current is potentially available to the gill tissue. The low values of $E_{w \max }$ in the perfusion experiments, therefore, imply that the perfusion bypassed the gills. This was confirmed by the finding of identical transport kinetics of oxygen uptake in a perfused mussel before and after excision of the gills (Table 1). The findings of similar and low values of $E_{\text {wmax }}$ in the absence as in the presence of gills, as well as of normal rates of oxygen uptake in perfused mussels, is direct evidence that the general surface of the mantle cavity has become the predominant respiratory site in the mussel and probably other filter feeding bivalves.

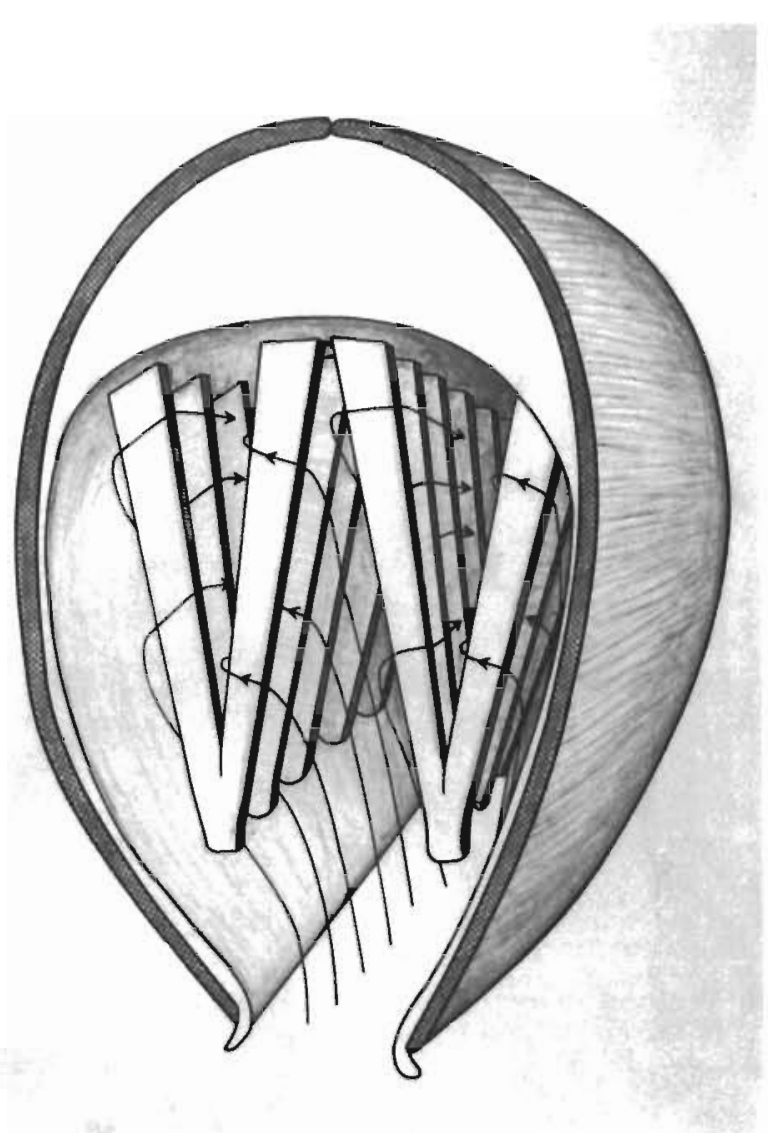

Fig. 8. Mytilus edulis. Diagrammatic presentation of pattern of ventilatory currents through mantle cavity and gills. Only 2 out of the 4 demibranchs are drawn. The current enters through the inhalant aperture, as indicated in Fig. 7, disperses into numerous micro currents at the level of the interfilamentary spaces, and unites again in the suprabranchial space and the exhalant siphon

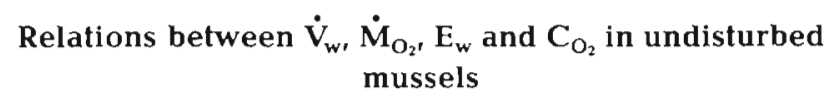

The experiments of Famme \& Kofoed (1980) and Famme (1980b) clearly indicated that oxygen consumption depends upon diffusional parameters prevailing within mantle cavity and tissues. These results were obtained by artificial ventilation of the mantle cavity. We have corroborated them in intact mussels ventilating under optimal conditions.

Mussels were fixed with quick adhesive in U-shaped holders (Fig. 9) and acclimated for 1 mo or more. They were fed continuously on the alga Phaeodactylum tricornutum added to the through flow at concentrations of about 3000 cells $\mathrm{ml}^{-1}$. Ventilation was measured as the clearance of suspensions of $P$. tricornutum according to Riisgård \& Randløv (1981). The concentration of algae in suspension was adjusted so that the ingestion rates in the mussels were kept constant. The 
ventilation rates were graduated by controlling the gaping of the valves by means of a screw as shown in Fig. 9. Under optimal conditions of feeding the adductor muscle is relaxed and the valves open passively. The physical constraint on gaping imposed by the screw presumably did not affect the mussel. The opening of the valves passively followed changes in the space available as controlled by turning the screw one way or the other.

Concurrently with the measurements of ventilation, oxygen consumption was determined as described by Møhlenberg \& Kiørboe (1981). At unrestricted flow, 3 mussels filtered 17 to $25 \mathrm{l}$ of water for each $\mathrm{ml}$ of oxygen consumed, and the extraction of oxygen varied from 0.012 to 0.008 . With the reduction in ventilation rate the extraction of oxygen increased, so that oxygen consumption declined only moderately compared with the decline in ventilation (Fig. $10 \mathrm{~A}, \mathrm{~B}, \mathrm{C}$ ). A reduction of $\dot{V}_{w}$ of about $50 \%$ resulted in a reduction in $\dot{\mathrm{M}}_{\mathrm{O}_{2}}$ of only 7 to $9 \%$, and a reduction in $\dot{V}_{w}$ of about $80 \%$ reduced $\dot{\mathrm{M}}_{\mathrm{O}_{2}}$ by only $20 \%$. At the prevailing relatively constant oxygen tension, corresponding to 75 to $90 \%$ saturation, oxygen clearance $\mathrm{C}_{\mathrm{O}_{2}}$ parallelled $\dot{\mathrm{M}}_{\mathrm{O}_{2}}$.
Fig. 10 shows the relative independence of $\mathrm{C}_{\mathrm{O}_{2}}$ upon $\dot{\mathrm{V}}_{w}$ at rates of $\dot{V}_{w}$ down to about $20 \%$ of the optimal rates, below which $\mathrm{C}_{\mathrm{O}_{2}}$ became strongly dependent upon $\dot{\mathrm{V}}_{\mathrm{w}}$.

The relations between mass specific values of $\dot{\mathrm{M}}_{\mathrm{O}_{2}}$ and $\dot{V}_{w}$ in the 3 mussels are shown in Fig. 11. Two of the mussels exhibited identical relations, whereas in the third the rate of oxygen consumption increased faster with increasing ventilation rate. This difference was correlated with differences in nutritional condition, the condition index of the mussel showing the faster increase in $\dot{M}_{\mathrm{O}_{2}}$ with $\dot{V}_{\mathrm{w}}$ being 2.65 , against 3.41 and 3.72 in the 2 other mussels.

To facilitate comparisons between naturally ventilating and artificially ventilated mussels, $\dot{\mathrm{M}}_{\mathrm{O}_{2}}$ values were calculated at $\mathrm{P}_{\mathrm{O}_{2}}=130 \mathrm{~mm} \mathrm{Hg}$ in the perfusion experiment of Famme \& Kofoed (1980), and the data were inserted in Fig. 11. Unfortunately, the exact body mass of the mussel was not recorded, the mass being estimated from the oxygen consumption rate (Per Famme pers. comm.). The nutritional condition of this mussel is, therefore, not known. The general relation between $\dot{M}_{\mathrm{O}_{2}}$ and $\dot{\mathrm{V}}_{\mathrm{w}}$ is, however, similar to that of the naturally ventilating mussels. It may be noted that the
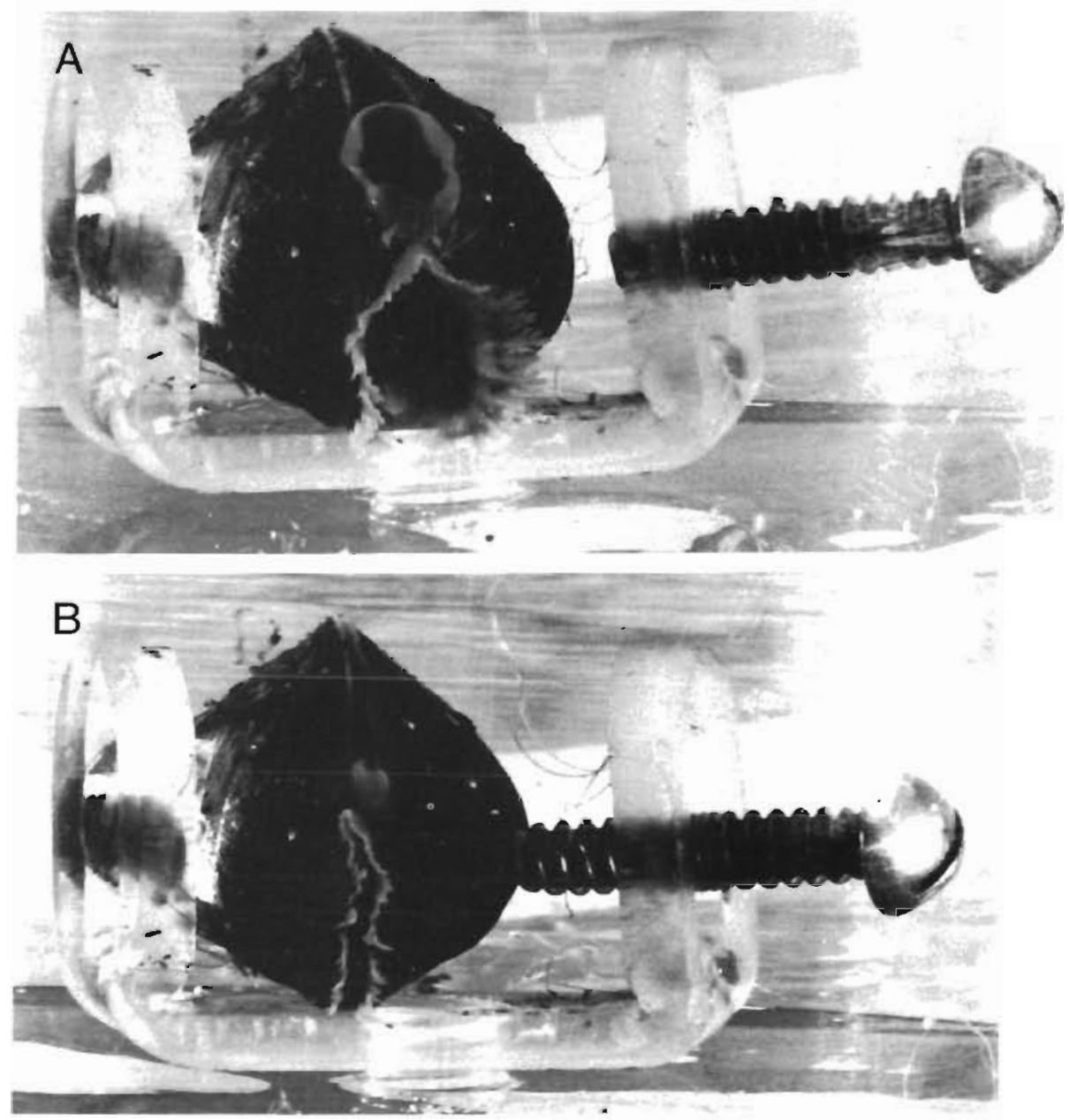

Fig. 9. Mytilus edulis Set-up used to study the effect on ventilation rates of passively controlling gap. ing of the valves by means of a screw. (A) The fully open $5.2 \mathrm{~cm}$ long mussel ventilated at a rate of $67 \mathrm{ml} \mathrm{min}^{-1}$ (B) at reduced gape, the rate was $29 \mathrm{ml} \mathrm{min}^{-1}$ 
Fig. 10. Mytilus edụlis. Effects of restrained ventilation $\dot{V}_{w}$ on oxygen consumption $\mathrm{M}_{\mathrm{O}_{2}}$ oxygen extraction $\mathrm{E}_{\mathrm{w}}$, and oxygen clearance $\mathrm{C}_{\mathrm{O}_{2}}$, in 3 mussels $\mathrm{A}, \mathrm{B}$. and $\mathrm{C}$

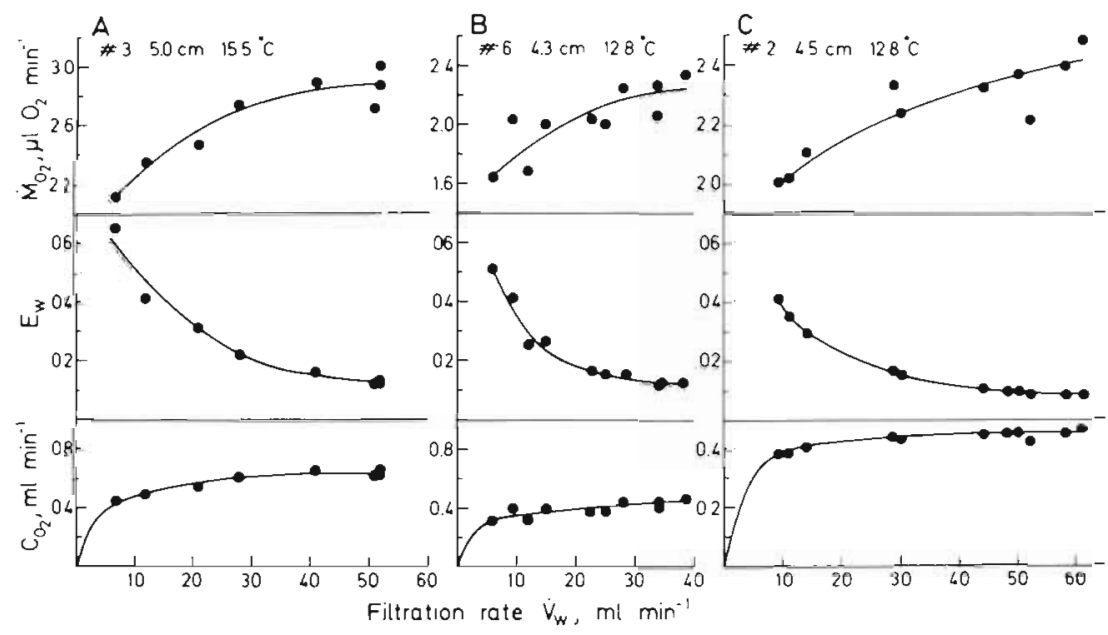

highest rate of artificial ventilation equalled unrestricted ventilation in mussels processing the water under optimal conditions.

We can now interpret the relations between ventilation and oxygen consumption in terms of resistance to diffusion of oxygen across the boundary layer at the interphase and within the tissues of the body. At low ventilation rates the boundary layer is thick whereas the diffusional pathways within the tissues tend to be short because most of the oxygen that diffuses into the tissues is consumed peripherally. $\dot{\mathrm{M}}_{\mathrm{O}_{2}}$ thus tends to be determined by the diffusional resistance across the boundary layer and, therefore, approaches proportionality with $\mathrm{P}_{\mathrm{O}_{2}}$. At high $\dot{\mathrm{V}}_{\mathrm{w}}$ the thickness of the boundary layer is reduced and diffusion through the tissues becomes correspondingly important in determining the relations between $\mathrm{P}_{\mathrm{O}_{2}}$ and $\dot{\mathrm{M}}_{\mathrm{O}_{2}}$. At low $\mathrm{P}_{\mathrm{O}_{2}}$ the oxygen diffusing into the tissues is consumed peripherally. The diffusional pathways are short and $\dot{\mathrm{M}}_{\mathrm{O}_{2}}$ increases steeply with increasing $\mathrm{P}_{\mathrm{O}_{2}}$. As the oxidative capacity of the peripheral tissues becomes saturated, oxygen gradually diffuses deeper into the tissues with increasing $\mathrm{P}_{\mathrm{O}_{2}}$ implying longer diffusional pathways and correspondingly higher diffusive resist-

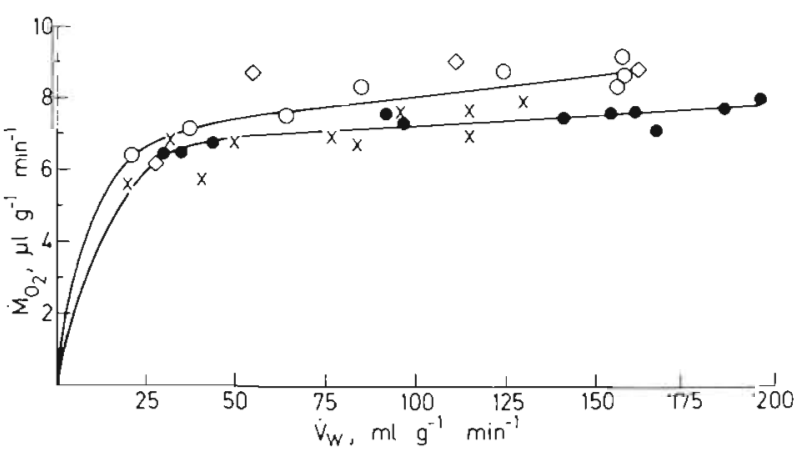

Fig. 11. Mytilus edulis. Relations between mass-specific ventilation $\dot{V}_{w}$ and oxygen consumption $\dot{M}_{\mathrm{O}_{2}}$ in $(\bullet, 0, x)$ naturally ventilating and $(0)$ artificially ventilated mussels ance, or lower rates of increase in $\dot{\mathrm{M}}_{\mathrm{O}_{2}}$ with increase in $\mathrm{P}_{\mathrm{O}_{2}}$. The relation can be described as a hyperbolic function, as shown by Famme \& Kofoed (1980). The 'half-saturation constant' of the function is determined by the ratio of internal/external diffusion resistance, thus decreasing with increasing ventilation rates (Famme \& Kofoed 1980) and with increasing body mass and condition (Famme 1980b).

\section{Oxygen extraction and filter feeding}

Marine filter feeders from coastal waters of the temperate zone typically process the ambient water at rates of $\geqslant 15 \mathrm{l}$ for each $\mathrm{ml}$ of oxygen consumed (Jørgensen 1975). At air saturation this corresponds to an extraction efficiency of $\leqslant 1 \%$. Extraction coefficients of oxygen recorded in the literature for filter feeding bivalves and other filter feeders usually vary from a few to about $10 \%$ (Mangum \& Burnett 1975 , Shumway 1983). Such values greatly overlap with the extractions as measured in non-filter-feeding burrowdwelling invertebrates, such as the polychaete worms Pectinaria gouldi (Mangum \& Burnett 1975) and Nereis spp. (Kristensen 1981), and the crustacean Upogebia affinis (Mangum \& Burnett 1975). High extraction values in filter feeders indicate that the measurements have been made on suboptimally ventilating animals, under conditions where diffusional constraints within the mantle cavity determine the rate of oxygen uptake.

\section{CONCLUSIONS AND PERSPECTIVES}

Ventilation and respiration in filter feeders are good examples of functions whose relations can only be understood when viewed from the level of the animal integrated with its environment. Filter feeders process the ambient water at inherent rates, adapted to the 
prevailing concentration of particulate food (Jørgensen 1966, 1975). This concentration varies with the habitat, and outside the tropics it also varies seasonally with the growth of the phytoplankton. In habitats with varying food concentration the filter feeders presumably have evolved water processing capacities that secure a positive energy balance of the organism during the productive periods of the year. In coastal-water filterfeeders, processing about $15 \mathrm{l}$ or more of water for each $\mathrm{ml}$ of oxygen consumed, the oxygen extraction efficiency is about $1 \%$ or less, at air saturation of the water. Filter feeders inhabiting less productive environments process correspondingly larger volumes of water and extract smaller proportions of oxygen.

In most filter feeders the ventilatory currents greatly exceed the currents typical of animals that breathe by gills. This is especially conspicuous in filter feeders, such as the bivalves, in which respiratory currents were adopted to serve as feeding currents. The remodelling to filter feeding structures presumably rendered the gills less fit for exchange of gases between the circulating blood and the ventilatory current, and the respiratory function passed to the general surface of the mantle cavity. The originally integrated function of blood circulation and ventilation do not seem to have been re-established elsewhere within the mantle cavity.

The transfer of oxygen uptake from the gills to other parts of the mantle cavity implied the substitution of a site structurally adapted for efficient diffusional uptake of oxygen by inefficient sites, where the thickness of the diffusive boundary layer is small compared with the thickness of the laminar currents passing the surface. Consequently, only small fractions of the oxygen carried with the ventilatory currents are available for respiration. This may constitute the basic characteristic of filter feeding, whether established in tubedwelling worms or in ciliary feeding bivalves, that only the suspended food in the ventilatory current is potentially available. It may, therefore, be misleading to speak about ventilation being grossly overdimensioned for the respiratory purpose that ventilation also serves. The smaller the fraction of oxygen available the larger the ventilation must be before diffusion through the boundary layer ceases to be limiting for the oxygen consumption. The correlations observed between respiration and ventilation in filter feeders thus reflect physical conditions of viscous flow and diffusive boundary layers, rather than physiological costs of ventilation or ventilatory regulation of respiration, and terms with physiological implications, like 'regulating' and 'conforming', are misleading when applied to respiration in filter feeders.

Moreover, the range within which oxygen consumption increases strongly with ventilation seems to apply only to the low ventilatory rates typical of adverse environmental conditions. Under optimum conditions filter feeders process the ambient water at rates that are usually well above these limiting rates for the diffusional uptake of oxygen, as indicated by the clearing of oxygen approaching independency of ventilation. Presumably, therefore, in habitats that require water-processing for feeding amounting to $\geqslant 15 \mathrm{I}$ for each $\mathrm{ml}$ of oxygen consumed, regulation of ventilation has ceased to be a means by which to regulate respiration.

\section{APPENDIX}

Calculation of oxygen profiles developing in the ventilatory current passing along the surface or Urechis caupo

\section{By Ove Sten-Knudsen}

$$
\begin{aligned}
& \text { Let } \\
& \mathrm{h}=\text { thickness of water envelope } \\
& \mathrm{X}=\text { distance in the direction of axis of worm } \\
& \mathrm{Y}=\text { distance from surface of worm, } 0<\mathrm{Y}<\mathrm{h} \\
& \mathrm{C}^{\circ} \quad=\text { oxygen concentration of the inflowing } \\
& \text { water } \\
& \mathrm{C}(\mathrm{Y}, \mathrm{t})=\text { oxygen concentration at position } \mathrm{Y} \text { and } \\
& \text { time } \mathrm{t} \\
& \text { D }=\text { diffusion coefficient of oxygen in water } \\
& \mathrm{v} \quad=\text { convection velocity of water enveloping } \\
& \text { the worm. }
\end{aligned}
$$

Since the thickness of the water envelope is much smaller than the diameter of the worm the diffusion can be regarded as 1-dimensional. Furthermore, the displacement per unit time of the oxygen molecules caused by the water flow $(1$ to $10 \mathrm{~cm}$ ) is much larger than the average displacement per unit time due to the random walk of the oxygen molecules $(0.005 \mathrm{~cm})$. Diffusion in the direction of the water flow will, therefore, have a minor influence on the concentration profile, the shape of which will be dominated by the diffusion through the surface of the worm. Thus, we have to solve

$$
\frac{\delta \mathrm{C}}{\delta \mathrm{t}}=\mathrm{D} \frac{\delta^{2} \mathrm{C}}{\delta \mathrm{Y}^{2}}
$$

with the boundary conditions

$$
\begin{aligned}
\mathrm{C} & =0, & & \text { for } \mathrm{Y}=0 \text { and } \mathrm{t}>0 \\
\delta \mathrm{C} / \delta \mathrm{t} & =0, & & \text { for } \mathrm{Y}=\mathrm{h} \text { and } \mathrm{t}>0
\end{aligned}
$$

and the initial condition

$$
\mathrm{C}=\mathrm{C}^{\circ}, \quad \text { for } \mathrm{t}=0 \text { and } 0 \leqslant \mathrm{Y} \leqslant \mathrm{h}
$$

The solution of Eq. (1) which also satisfies the conditions Eq. (2), Eq. (3) and Eq. (4) is 


$$
\begin{aligned}
& C(Y, t)=\frac{4 C^{\circ}}{\pi} \sum_{n=0}^{\infty} \frac{\sin [(2 n+1) \pi Y / 2 h]}{2 n+1} \\
& \exp \left\{-D\left(\frac{(2 n+1) \pi}{2 n}\right)^{2} t\right\} \\
& n=0,1,2, \ldots
\end{aligned}
$$

(see e.g. Carslaw \& Jaeger 1956). The concentration profile $\mathrm{C}(\mathrm{Y}, \mathrm{t})$ will be found at the position

$$
\mathrm{X}=\mathrm{vt}
$$

since the water reaching the anterior end of the worm at time $\mathrm{t}=0$ will at time $\mathrm{t}$ be located at the distance $\mathrm{X}$ from the anterior end.

Inserting Eq. (6) in Eq. (5) gives the following expression for the concentration profile in the water mantle 0 $<\mathrm{Y}<\mathrm{h}$ at the distance $\mathrm{X}$ from the anterior end

$$
\begin{aligned}
& C(Y, t)=\frac{4 C^{\circ}}{\pi} \sum_{n=0}^{\infty} \frac{\sin [(2 n+1) \pi Y / 2 h]}{2 n+1} \\
& \exp \left\{-D\left(\frac{(2 n+1) \pi}{2 n}\right)^{2} \frac{X}{v}\right\} \\
& n=0,1,2, \ldots
\end{aligned}
$$

which was used to calculate the profiles of Fig. 2.

\section{LITERATURE CITED}

Aiello, E. L., Guideri, G. (1965). Distribution and function of the branchial nerve in the mussel. Biol. Bull. mar biol. Lab., Woods Hole 129: 431-438

Alexander, R. McNeill (1975). The chordates. Cambridge University Press, London

Bayne, B. L. (1967). The respiratory response of Mytilus perna L. (Mollusca: Lamellibranchia) to reduced environmental oxygen. Physiol. Zool. 40: 307-317

Bayne, B. L. (1971a). Oxygen consumption by three species of lamellibranch molluscs in declining ambient oxygen tension. Comp. Biochem. Physiol. 40 A: 955--970

Bayne, B. L. (1971b). Ventilation, the heart beat and oxygen uptake by Mytilus edulis $\mathrm{L}$. in declining oxygen tension. Comp. Biochem. Physiol. 40 A: 1065-1085

Bayne, B. L. (ed.) (1976). Marine mussels: Their ecology and physiology. Cambridge University Press, Cambridge

Bayne, B. L., Newell, R. C. (1983). Physiological energetics of marine molluscs. In: Wilbur, K. M. (ed.) The Mollusca, Vol. 4, Part 1. Academic Press, New York, p. 407-515

Bayne, B. L., Scullard, C. (1977). An apparent specific dynamic action in Mytilus edulis L. J. mar. biol. Ass. U.K. 57: 371-378

Bayne, B. L., Thompson, R. J., Widdows, J. (1973). Some effects of temperature and food on the rate of oxygen consumption by Mytilus edulis L. In: Wieser, W. (ed.) Effects of temperature on ectothermic organisms. Springer, Berlin, p. 181-193

Bayne, B. L., Bayne, C. J., Carefoot, T. C., Thompson, R. J. (1976). The physiological ecology of Mytilus californianus Conrad. Oecologia (Berl.) 22: 211-228

Bernard, F. R. (1983). Physiology and the mariculture of some northeastern Pacific bivalve molluscs. Can. Spec. Publ. Fish. Aq. Sci. 63: 1-24
Booth, C. E., Mangum, C. P. (1978). Oxygen uptake and transport in the lamellibranch mollusc Modiolus demissus. Physiol. Zool. 51: 17-32

Brand, A. R., Morris, D. J. (1984). The respiratory responses of the dog cockle Glycymeris glycymeris (L.) to declining environmental oxygen tension. J. exp. mar Biol. Ecol. 83: 89-106

Brand, A. R., Taylor, A. C. (1974). Pumping activity of Arctica islandica (L.) and some other common bivalves. Mar. Behav. Physiol. 3: 1-15

Brown, S. C. (1977). Biomechanics of water-pumping by Chaetopterus variopedatus Renier: Kinetics and hydrodynamics. Biol. Bull. mar biol. Lab., Woods Hole 153: $121-132$

Carslaw, H. S., Jaeger, J. C. (1956). Conduction of heat in solids. Oxford University Press, London

Chapman, G. (1968). The hydraulic system of Urechis caupo Fisher \& MacGinitie. J. exp. Biol. 49: 657-667

Coleman, N. (1974). The heart rate and activity of bivalve molluscs in their natural habitats. Oceanogr. mar. Biol. A. Rev. 12: 301-313

Collier, A. (1959). Some observations on the respiration of the American oyster Crassostrea virginica (Gmelin). Inst. Mar. Sci. 6: $92-108$

Dejours, P. (1972). Comparison of gas transport by convection among animals. Resp. Physiol. 14: 96-104

Dejours, P., Garey, W. F., Rahn, H. (1970). Comparison of ventilatory and circulatory flow rates between animals in various physiological conditions. Resp. Physiol. 9: 108-117

Famme, P. (1980a). Effect of shell valve closure by the mussel Mytilus edulis $\mathrm{L}$. on the rate of oxygen consumption in declining oxygen tension. Comp. Biochem. Physiol. 67 A: $167-170$

Famme, P. (1980b). Oxygen-dependence of the respiration by the mussel Mytilus edulis L. as a function of size. Comp. Biochem. Physiol. 67 A: 171-174

Famme, P. (1981). Haemolymph circulation as a respiratory parameter in the mussel, Mytilus edulis L. Comp. Biochem. Physiol. 69 A: 243-247

Famme, P., Kofoed, L. H. (1980). The ventilatory current and ctenidial function related to oxygen uptake in declining oxygen tension by the mussel Mytilus edulis L. Comp. Biochem. Physiol. 66 A: 161-171

Fenchel, T. (1980). Relation between particle size selection and clearance in suspension-feeding ciliates. Limnol. Oceanogr. 25: 733-738

Fenchel, T (1982). Ecology of heterotrophic microflagellates. II. Bioenergetics and growth. Mar. Ecol. Prog. Ser. 8: 225-231

Fenchel, T., Finlay, B. J. (1983). Respiration rates in heterotrophic, free-living Protozoa. Microb. Ecol. 9: 99-122

Fisher, W. K., MacGinitie, G. E. (1928). The natural history of an echiuroid worm. Ann. Mag. Nat. Hist. 10: 204-213

Foster-Smith, R. L. (1976). Pressures generated by the pumping mechanism of some ciliary filter feeders. J. exp. mar. Biol. Ecol. 25: 199-206

Foster-Smith, R. L. (1978). An analysis of water flow in tubeliving animals. J. exp. mar. Biol. Ecol. 34: 73-95

Fry, F. E. (1947). Effects of the environment on animal activity. Publ. Ontario Fish. Res. Lab. 68: 1-62

Ghiretti, F. (1966). Respiration. In: Wilbur, K. M., Yonge, C. M. (ed.) Physiology of Mollusca, Vol. 2. Academic Press, New York, p. 175-208

Griffiths, C. L., King, J. A. (1979). Some relationships between size, food availability and energy balance in the ribbed mussel Aulacomya ater. Mar. Biol. 51: 141-149

Hall, V. E. (1931). The muscular activity and oxygen consump- 
tion of Urechis caupo. Biol. Bull. mar biol. Lab., Woods Hole 61: 400-416

Hamwi, A., Haskin, H. H. (1969). Oxygen consumption and pumping rates in the hard clam Mercenaria mercenaria: A direct method. Science 163: 823-824

Holeton, G. F. (1970). Oxygen uptake and circulation by a haemoglobinless antarctic fish (Chaenocephalus aceratus Lonnberg) compared with three red-blooded antarctic fish. Comp. Biochem. Physiol. 34: 457-471

Jørgensen, B. B., Revsbech, N. P. (1984). Boundary layers and the diffusive oxygen uptake of sediments and detritus. Limnol. Oceanogr. 30: 111-122

Jørgensen, C. B. (1955). Quantitative aspects of filter feeding in invertebrates. Biol. Rev. 30: 391-454

Jørgensen, C. B. (1966). Biology of suspension feeding. Pergamon Press, Oxford

Jørgensen, C. B. (1975). Comparative physiology of suspension feeding. A. Rev. Physiol. 37: 57-79

Johansen, K., Lenfant, C., Mecklenberg, T. A. (1970). Respiration in the crab, Cancer magister. Z. vergl. Physiol. 70: 1-19

Kiørboe, T., Møhlenberg, F., Nohr, O. (1981). Effect of suspended bottom material on growth and energetics in Mytilus edulis. Mar. Biol. 61: 283-288

Koch, H.-J., Hers, M.-J. (1943). Influence de facteurs respiratoires sur les interruptions de la ventilation par le siphon exhalant chez Anodonta cygnea L. Annls Soc. r. z. Belg. 74: 32-44

Kristensen, E. (1981). Direct measurement of ventilation and oxygen uptake in three species of tubicolous polychaetes (Nereis spp.). J. Comp. Physiol. 145: 45-50

Krogh, A. (1941). The comparative physiology of respiratory mechanisms. University of Pennsylvania Press

Lawry, J. V. Jr. (1966). Neuromuscular mechanisms of burrow irrigation in the echiuroid worm Urechis caupo Fisher \& MacGinitie. J. exp. Biol. 45: 343-356

Lowe, G. A., Trueman, E. R. (1972). The heart and water flow rates of Mya arenaria (Bivalvia: Mollusca) at different metabolic levels. Comp. Biochem. Physiol. 41 A: 487-494

Mangum, C. P., Burnett, L. E. (1975). The extraction of oxygen by estuarine invertebrates. In: Vernberg, F. J. (ed.) Physiological ecology of estuarine organisms. University of South Carolina Press, Columbia, p. 147-163

Møhlenberg, F., Kiørboe, T (1981). Growth and energetics in Spisula subtruncata (da Costa) and the effect of suspended bottom material. Ophelia 20: 79-90

Møhlenberg, F, Riisgård, H. U. (1979). Filtration rate, using a new indirect technique, in thirteen species of suspensionfeeding bivalves. Mar. Biol. 54: 143-148

Navarro, J. M., Winter, J. E. (1982). Ingestion rate, assimilation efficiency and energy balance in Mytilus chilensis in relation to body size and different algal concentrations. Mar. Biol. 67: 255-266

Newell, R. C. (1970). Biology of intertidal animals, Logos Press, London

Newell, R. C., Branch, G. M. (1980). The influence of temperature on the maintenance of metabolic energy balance in marine invertebrates. Adv. mar. Biol. 17: 329-396

Newell, R. C., Kofoed, L. H. (1977). The energetics of suspension-feeding in the gastropod Crepidula fornicata L. J. mar biol. Ass. U.K. 51: 161-180

Newell, R. C., Pye, V. J. (1970). Seasonal changes in the effect of temperature on the oxygen consumption of the winkle Littorina littorea (L.) and the mussel Mytilus edulis (L.). Comp. Biochem. Physiol. 34: 367-383

Newell, R. C., Johnson, L. G., Kofoed, L. H. (1977). Adjustment of the components of energy balance in response to temperature change in Ostrea edulis. Oecologia (Berl.) 30: 97-110

Newell, R. I. E., Bayne, B. L. (1980). Seasonal changes in the physiology, reproductive condition and carbohydrate content of the cockle Cardium (= Cerastoderma) edule(Bivalvia: Cardiidae) Mar. Biol. 56: 11-19

Piiper, J, Dejours, P., Haab, P., Rahn, H. (1971). Concepts and basic quantities in gas exchange physiology. Resp. Physiol. 13: 292-304

Pritchard, A., White, F. N. (1981). Metabolism and oxygen transport in the innkeeper Urechis caupo. Physiol. Zool. 54: 44-54

Rahn, H. (1966). Aquatic gas exchange: theory. Resp. Physiol. 1: $1-12$

Randall, D. J. (1970). Gas exchange in fish. In: Hoar, W. S., Randall, D. J. (ed.) Fish physiology, Vol. IV. Academic Press, New York, p. 252-292

Revsbech, N. P., Jargensen, B. B. (1985). Microelectrodes: Their use in microbial ecology. Adv. microb. Ecol (in press)

Riisgård, H. U., Randløv, A. (1981). Energy budgets, growth and filtration rates in Mytilus edulis at different algal concentrations. Mar. Biol. 61: 227-234

Riisgård, H. U., Randløv, A., Hamburger, K. (1981). Oxygen consumption and clearance as a function of size in Mytilus edulis L. veliger larvae. Ophelia 20: 179-183

Shumway, S. E. (1983). Factors affecting oxygen consumption in the coot clam Mulinia lateralis (Say). Ophelia 22: 143-171

Taylor, A. C. (1976a). The cardiac responses to shell opening and closure in the bivalve Arctica islandica (L.). J. exp. Biol. 64: 751-759

Taylor, A. C. (1976b). Burrowing behaviour and anaerobiosis in the bivalve Arctica islandica (L.). J. mar. biol. Ass. U.K. 56: $95-109$

Taylor, A. C. (1975). A comparative study of the respiratory responses of the bivalves Arctica islandica (L.) and Mytilus edulis $\mathrm{L}$. to declining oxygen tension. Proc. R. Soc. Lond. B. 190: 443-456

Thompson, R. J., Bayne, B. L. (1972). Active metabolism associated with feeding in the mussel Mytilus edulis L. J. exp. mar Biol. Ecol. 9: 111-124

Thompson, R. J., Livingstone, D. R., de Zwaan, A. (1980) Physiological and biochemical aspects of the valve snap and valve closure responses in the giant scallop Placopecten magellanicus. J. comp. Physiol. 137: 97-104

Verduin, J. (1969). Hard clam pumping rates: Energy requirements. Science 166: 1309-1310

Vogel, S. (1981). Life in moving fluids. Willard Grant Press, Boston, Massachusetts

Walne, P. R. (1972). The influence of cursent speed, body size and water temperature on the filtration rate of five species of bivalves. J. mar. biol. Ass. U.K. 52: 345-374

White, K. M. (1937). Mytilus. L.M.B.C. Mem. typ. Br mar. Pl. Anim. 31 University Press, Liverpool

Widdows, J. (1973). The effects of temperature on the metabolism and activity of Mytilus edulis. Neth. J. Sea Res. 7: 387-398

van Winkle, W. (1975). Problems in establishing the relationship between pumping rate and oxygen consumption rate in the hard clam, Mercenaria mercenaria. Comp. Biochem. Physiol, 50 A: 657-660

Winter, J. E., Langton, R. W. (1975). Feeding experiments with Mytilus edulis L. at small laboratory scale. In: Persoone, G., Jaspers, E. (ed.) 10th Eur. Mar. Biol. Symp. Vol. 1. Universa Press, Wetteren, p. 565-581 